\title{
Entrenchment of Ordinary Legislation: A Reply to Professors Posner and Vermeule
}

\author{
John C. Roberts $\dagger$ and Erwin Chemerinsky $\ddagger$
}

\section{TABLE OF CONTENTS}

Introduction

I. What is Entrenchment of Ordinary Legislation?

A. Definitions and Qualifications

B. Are There Actual Examples of Entrenchment?

II. Is Entrenchment of Ordinary Legislation Consistent With the Specific Provisions of the Constitution?

A. The "Vesting Clause" of Article I, Section 1........................... 1783

B. The Article V Amendment Power ............................................ 1785

C. The Argument from Electoral Cycles ...................................... 1789

D. The Rulemaking Clause of Article I ....................................... 1789

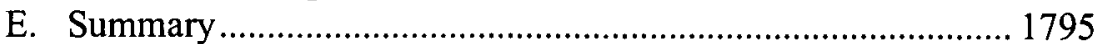

III. Is Entrenchment of Ordinary Legislation Consistent With the

Underlying Principles of Our Representative Democracy?

A. The Principle of Democratic Accountability ........................... 1796

B. Majoritarianism in Enacting Ordinary Legislation ................... 1798

C. The Framers' Experiences With Legislative Bodies ................ 1799

1. State Legislatures ......................................................... 1801

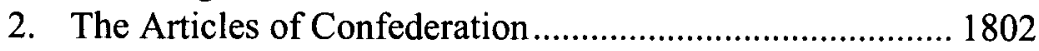

3. Summary ..................................................................... 1805

IV. Is Entrenchment of Ordinary Legislation Wise as a Matter of National Policy?

A. The Purported Benefits of Legislative Entrenchment............... 1806

Copyright (C) 2003 California Law Review, Inc. California Law Review, Inc. (CLR) is a California nonprofit corporation. CLR and the authors are solely responsible for the content of thcir publications.

$\dagger \quad$ Professor of Law and Dean Emeritus, DePaul University College of Law. 1 am indebted to Betsy Lane for her research assistance and to Dean Waync Lewis for his support through the DePaul Faculty Research Fund.

$\ddagger \quad$ Sydney M. Irmas Professor of Public Interest Law, Legal Ethics, and Political Science, University of Southern California. I want to thank Jennifer Fercovich for her excellent rcsearch assistance. 
B. The Dangers of Entrenchment .................................................. 1809

1. Temporary Radical Majorities ......................................... 1809

2. Changing National Consensus........................................... 1810

3. Changing Social and Economic Conditions..................... 1811

4. Budget Fluctuations..................................................... 1812

5. Technical Errors ............................................................. 1812

6. Emergency Measures .................................................... 1813

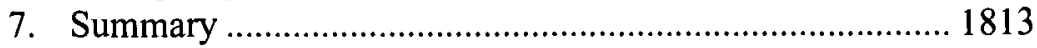

V. Are the Real World Obstacles to Ordinary Legislation

Equivalent to Entrenchment? ...................................................... 1813

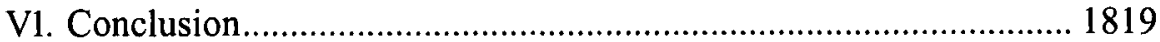




\title{
Entrenchment of Ordinary Legislation: A Reply to Professors Posner and Vermeule
}

\author{
John C. Roberts and Erwin Chemerinsky
}

\section{INTRODUCTION}

Imagine that you live in a state that traditionally imposes the death penalty for certain capital offenses. Through a series of unusual events, a coalition develops in the legislature that favors abolishing the death penalty. The legislators realize, however, that their majority is temporary and unlikely to be replicated in future years. Indeed, voters in the state strongly favor the death penalty and are likely to react to its repeal by electing a different group of representatives who will enact a new law allowing capital punishment. The legislators thus fear that if they abolish the death penalty, their successors will simply reinstate it. To forestall this possibility, those favoring abolition come up with a simple solution. They include a provision in the bill providing that repeal of the statute requires three-fourths approval of both houses of the state legislature.

Now imagine that both houses of Congress are closely divided ideologically, and particularly so on the abortion issue. Year after year, fights erupt in both the House and the Senate over whether there will be federal government funding for abortions. When the Republicans are in the majority, they vote to prohibit government money from being used to pay for abortions. When the Democrats are in control, they provide public funds to indigent women for abortions. During a period in which the Republicans have control of both houses, however, they decide to end the fight once and for all: they pass a bill banning the use of federal funds for abortion and include a textual provision flatly prohibiting repeal of the funding ban by future Congresses.

Are such laws constitutional? The conventional wisdom is that they are not, because one legislature cannot bind a future legislature. This practice is commonly referred to as legislative entrenchment and it is widely regarded as inconsistent with basic principles of democracy. ${ }^{1}$ As Professor

1. For particularly cogent diseussions of the problems with entrenchment, see Julian N. Eule, Temporal Limits on the Legislative Mandate: Entrenchment and Retroactivity, 1987 AM. B. Found. 
Klarman explains, entrenchment is "inconsistent with the democratic principle that present majorities rule themselves." If a legislature wishcs to bind future legislatures, it must invoke the constitutional amendment process.

In a recent essay, however, Professors Eric A. Posner and Adrian Vermeule challenge the basis of this well-established rule. They argue that "entrenchment is both constitutionally permissible and, in appropriate circumstances, normatively attractive."3 They explore a variety of justifications for the idea that one legislature should have the power to bind future ones, and their ideas deserve serious debate. For if entrenchment of ordinary legislation were to become a permissible weapon in the legislative arsenal, the consequences to our legal system and, more broadly, to American society would be profound.

Professors Posner and Vermeule recognize no constitutional limit on the authority of legislatures to entrench statutes. Indeed, there is no logical stopping point to the view they propound. Any hard-fought legislative victory could be preserved by including an entrenchment provision that would make change difficult or impossible. In fact, though Posner and Vermeule focus exclusively on Congress's power to entrench legislation, their analysis would apply with equal force to state legislatures and city councils. A1lowing entrenchment at all these levels of government would radically change our general conception of how laws are enacted in a democratic society. ${ }^{4}$ Professors Posner and Vermeule provide an array of theoretical justifications for legislative entrenchment, but they fail to address fully the practical realities of their proposal. They freely acknowledge that legal philosophers, judges, and modern legal scholars have rejected the idea that one legislature, through ordinary legislation, should be allowed to bind future legislatures. ${ }^{5}$ At the same time, however, they do not seem to recognize the political fact that future legislatures could simply ignore attempts to restrict their freedom of action, and that courts would almost certainly refuse to give such attempts binding force. ${ }^{6}$ They assert that, despite the virtually unanimous views of everyone who has ever thought or written about the issue, we should be opcn to the idea of entrenchment as a normative matter. ${ }^{7}$

Res. J. 379; Michacl J. Klarman, Majoritarian Judicial Review: The Entrenchment Problem, 85 Geo. L.J. 491 (1997); see also Part IV, infra.

2. Klarman, supra note 1 , at 509.

3. Eric A. Posner \& Adrian Vermeule, Legislative Entrenchment: A Reappraisal, 111 YALE L.J. 1665, 1666 (2002).

4. In other words, future legislative majorities of the people's elected representatives would not have full freedom of legislative action. We elaborate on this point in Part lll.B, infra.

5. Posner \& Vermeule, supra note 3, at 1665 n.4.

6. We discuss the federal cases relevant to this point in Part II.D, infra.

7. In their recent contribution to the debate, Professors McGinnis and Rappaport agree that entrenchment of ordinary legislation is not permitted in our constitutional system but are strangely 
In this Essay, we argue that Professors Posner and Vermeule are wrong both as a matter of constitutional law and as a matter of desirable policy. One legislative majority should never be able to bind future legislative majorities by means of ordinary legislation. The well-established rule prohibiting legislative entrenchment, once described by Charles Black as an idea which is, "on the most familiar and fundamental principles, so obvious as rarely to be stated,"

Our critique of entrenchment is organized around a series of analytical questions, each designed to test the various arguments Posner and Vermeule offer. In Part I, we discuss the meaning and scope of the entrenchment principle and demonstrate that Posner and Vermeule fail to identify persuasively any current applications of this principle. In Part II, we examine whether entrenchment violates specific provisions of our federal Constitution, and conclude that it does. In Part III, we explore the related question of whether entrenchment violates the underlying democratic principles upon which the Constitution, as well as our entire political system, is based, and again we conclude that it does. In Part IV, we take direct issue with the normative justifications for entrenchment given by Posner and Vermeule, arguing that the idea of entrenchment deserves the oblivion from which those scholars have tried to rescue it. In Part V, we reply to the specific argument raised by Posner and Vermeule that entrenchment is in reality no worse than many other practical obstacles to the enactment of ordinary legislation. Finally, in Part VI, we conclude by summarizing our overall defense of the notion that no legislature may bind its successors.

\section{I}

\section{WHAT IS ENTRENCHMENT OF ORDINARY LEGISLATION?}

\section{A. Definitions and Qualifications}

First, we must clarify a few principles underlying our discussion. The term "entrenchment" has been used in a number of senses over the years, and we must ensure that its meaning is understood by our readers for the purposes of this response. Professors Posner and Vermeule give the term a simple definition, which we also adopt in our analysis. Entrenchment, they say, refers to "statutes or internal legislative rules that are binding against subsequent legislative action in the same form." In other words, it refers to

equivoeal on the question of whether entrenchment is always undesirable. They seem to argue that on some issues entrechment of ordinary legislation can be a good idea, so long as both the adopting and repealing legislatures are held to the same supermajority voting rules. John O. McGinnis \& Michael B. Rappaport, Symmetric Entrenchment: A Constitutional and Normative Theory, 89 VA. L. REv. 385 (2003).

8. Charles L. Black, Jr., Amending the Constitution: A Letter to a Congressman, 82 YALE L.J. 189,191 (1972).

9. Posner \& Vermeule, supra note 3, at 1667. 
ordinary legislation, not constitutional provisions. ${ }^{10}$ The concept covers both repeal and amendment of earlier legislation. It is important to emphasize that we are speaking about requirements made "binding" upon subsequent legislatures, a point which Posner and Vermeule seem to forget in their later discussion of outside factors affecting future legislation which they find equivalent to entrenchment." By "binding" we mean those requirements that the future legislature cannot waive or ignore in a legal sense, not just those factors that in the normal ebbs and flows of policy debate and party politics may make it difficult for Congress to act. ${ }^{12}$

One can imagine several different varieties of entrenchment provisions. Professor Eule, who wrote the first in-depth analysis of the concept, discusses four types. ${ }^{13}$ The first, "absolute entrenchment," means that a statute may not be repealed at all by a subsequent legislature. The second, "transitory entrenchment," refers to a requirement that a statute may not be repealed at all, but only for a specified time period. The third, "conditional entrenchment," covers cases where a statute may not be repealed unless a specified future condition, presumably something outside of the legislative branch itself, is satisfied. Finally, the fourth, "procedural entrenchment," encompasses a number of possible procedural requirements that must be met by a future legislature if it desires to repeal a particular legislative act. Most often, this category includes a supermajority voting requirement for repeal or amendment. As a practical matter, however, since we have so few examples of entrenchment of ordinary legislation in American law, such a detailed taxonomy is of limited usefulness. ${ }^{14}$

10. In Part II.B, infra, we address the relationship between entrenchment of ordinary legislation and entrenched constitutional provisions, which Professors Posner and Vermeule discuss.

11. See infra Part V.

12. We discuss barriers to legislation that are not binding in the legal sense in Part $V$, infra.

13. Eule, supra note 1 , at 379.

14. Professors McGinnis and Rappaport suggest an additional category, "symmetric entrenchment," in which a legislature cannot require a supermajority for repeal of a measure unlcss it adopts the measure pursuant to a pre-existing rule requiring the same supermajority. McGinnis \& Rappaport, supra note 7 , at 417,426 . In our vicw, this category adds little to the debate. Theoretically, it does not matter whether the entrenching vote is pursuant to a supermajority rule because the vice of entrenchment is its intrusion into the rights of the future legislature. All of the arguments both we and Professors McGinnis and Rappaport make to show that the Framers rejected supermajority rules for adoption of ordinary legislation apply with equal force to symmetric supermajority entrenchment. Most importantly, our conviction that entrenchment violates the Rulemaking Clause of the Constitution applies just as strongly to symmetric entrenchment. From a policy perspective, all of the arguments and historical examples we offer in Part V, infra, to show the practieal dangers of entrenchment apply equally well to symmetric entrenchment. Again, the key issue is not whether there is formal equality or "fairness" in the strictures placcd on two lcgislatures many years apart. Rather, the concern is the freedom of the second legislature to do what is needed for the country at the later time. Certain measures might well command largc majorities when adopted and yet prove to be unwise, unpopular, or overtaken by events. A supermajority requirement for adoption may increase somewhat the likelihood that a bill is actually supportcd by a majority of the people, but it does nothing to guarantee that the bill retains such support forever. It surely cannot increase the chanccs of the measure remaining good public policy for future generations. 
For purposes of this response, we instead refer to entrenchment in only two ways, as either "substantive" or "procedural." By "substantive entrenchment" we mean the legal (as opposed to political, social, or economic) requirements which would completely prevent a future legislature from amending or repealing an Act of Congress. ${ }^{15}$ This definition would therefore include not only Eule's idea of absolute entrenchment, but also conditional and transitory entrenchment, since they would also completely prevent modification or repeal for at least a limited period. By "procedural entrenchment," we mean any legislative provisions which specify certain procedures that must be followed by a subsequent legislature attempting to repeal or amend the law in question, including but not limited to requirements that a vote larger than a simple majority must be obtained for passage of the second bill.

Professors Posner and Vermeule acknowledge that the idea of entrenchment includes an absolute bar to repeal, but their discussion seems to eenter around the less drastic forms of entrenchment, like supermajority voting requirements. There is good reason for this tactical decision. The requirement that a particular law may not be repealed in the future, no matter what the changed circumstances or how strong the majority for repeal, is startling to contemplate and extremely hard to defend as a matter of wise national policy. Therefore, since "substantive entrenchment" presents entrenchment in its starkest form, we will emphasize it in the discussion that follows.

As we have noted, the principle that one legislative body may not bind its successors is common to all levels of our government and applies to any democratically elected law-making body. For simplicity, however, we will focus (as do Posner and Vermeule) on the constitutional and practical arguments against entrenchment at the federal level. Many, however, apply with equal force to state legislatures, city councils, and other such legislative bodies.

\section{B. Are There Actual Examples of Entrenchment?}

While their main focus is on the theoretical and practical justifications for entrenchment, Professors Posner and Vermeule devote some space in their essay to the question of whether there are actual examples of binding entrenchment in the history of legislative bodies. ${ }^{16}$ They come up with very few that bear even the slightest resemblance to entrenchment. ${ }^{17}$ Two of their examples, however, deserve some comment.

15. Like Professors Posner and Vermeule, we assume throughout that the President has signed the earlier bill containing the entrenchment provision, following the requirements of Article 1 , and that it is therefore an otherwise valid law at the time a future legislature attempts to repeal or amend it.

16. See Posner \& Vermeule, supra note 3, at 1677-79.

17. Professors Posner and Vermeule are clearly correct, for example, that Congressional efforts to place rules in statutes requiring supermajorities or other procedural requirements for future 
The first example is the tradition of unlimited debate in the Senate and the Cloture Rule that enforces it. ${ }^{18}$ Professors Posner and Vermeule argue that the existence of a procedural rule limiting the ability of a simple majority of the Senate to enact, amend, or repeal a bill is an example of entrenchment, proving that the concept must not be an alien one after all. ${ }^{19}$

There are a number of problems with the filibuster analogy. Most importantly, a simple majority of the Senate can arguably change or even eliminate the Cloture Rule, as occurred at least once in the past. ${ }^{20}$ This argument is buttressed by the Senate's modern practice of enacting by majority vote expedited-consideration rules that limit the ability of members to filibuster, as it did most recently in the Congressional Review Act. ${ }^{21}$ If it is correct that a simple majority of members of the Senate can change the rule, or suspend it for particular types of legislation, then the filibuster's power exists because of cultural and historical forces, not because of binding law. Viewed in this way, the filibuster is no longer an example of entrenchment because a majority can eliminate it. Moreover, even if we were to concede that the Cloture Rule as currently employed is in fact a single,

amendment or repeal have been ignored both by future Congresses and the courts. We discuss this in Part II.D. We also agree that statutes that attempt to limit future Congressional action, like GrammRudman-Hollings, are all waivable by future legislative majorities.

18. Senate Rule XXII currently provides that cloture may be invoked against a filibuster by a vote of three-fifths of senators holding office at the time and imposes various procedural restrictions to forestall further obstructionism after cloture has been invoked. In a further attempt to prevent changes in the Cloture Rule itself, Rule XXII also specifies that the rules may only be amended by two-thirds of those senators present and voting.

19. See Posner \& Vermeule, supra note 3, at I694-95.

20. During the 1950 s, advocates of civil rights legislation attempted to obtain rulings from the Chair that the Senate's rules expired after each Congress and that the Cloture Rule therefore could be defeated by a simple majority. They failcd, though Vice President Nixon, as presiding officer, issued an advisory ruling in 1957 saying that the Rulemaking Clause of the Constitution ensured the right of each new Senate to adopt its rules by simple majority (a position wc endorse). Vice President Humphrey made the same ruling in I967, but was not supportcd by a majority of the members. In I975, however, cloture opponents obtained a ruling from the Chair that debate on a rule change at the beginning of a new Congress could be closed by a simple majority. In a historic moment, the ruling was upheld by a vote of $5 \mathrm{I}-42$, in effect deciding that cloture could be invoked by a simple majority. There followed intense behind-the-scenes maneuvering which resulted in a compromise change in the Cloture Rule from two-thirds of those present to three-fifths of those elected. As part of the compromise, it was agreed that the previous vote would be reconsidered and wiped out, in effect reinstating the principle that cloture applied to rules changes as well. At the time, Senator Robert Byrd, the Senate's parliamentary expert, commented that, no matter how the Senate might try to cover its procedural tracks, it would now be clear to historians that a simple majority could ehange the Cloture Rule if aided by a sympathetic Chair and Majority Leader, 121 Cong. Rec. 5249 (1975); see also 2 Robert C. Byrd, the Senate I31-33 (I99I); Charles Tiefer, Congressional Practice and Procedure 70206 (I989).

2I. Originally enacted as Section 251 of the Contract With America Advancement Act, Pub. L. No. 104-I21, 110 Stat. 847 (I996), the Congressional Review Act's review mechanism is codified starting at 5 U.S.C. $\S 80 \mathrm{I}$. 
isolated example of procedural entrenchment, we would argue that the rule is unconstitutional for reasons discussed in the rest of this Essay. ${ }^{22}$

The second example of entrenchment in current law discussed by Professors Posner and Vermeule is the obligation of government contracts. How can it be argued, they ask, that one Congress can never bind a subsequent one, when contract obligations of governments are sometimes enforced by courts against attempts by future Congresses to repudiate or modify them $?^{23}$ Though this is a complex subject, we think once again that the example fails to support a general argument that entrenchment already exists.

First, this discussion is complicated by the involvement of separate constitutional principles. For states and municipalities, the Contracts Clause found in Article I, Section 10 of the Constitution limits the ability of the government to abrogate its own contracts without meeting heightened scrutiny. ${ }^{24}$ This specific constitutional limitation makes the usefulness of the contracts example as a general precedent questionable. Indeed, though we concede that the Constitution may, and does, contain specific entrenched provisions, we maintain that this fact has no bearing on the question of whether entrenchment of ordinary legislation is permitted as a general principle.

Second, the federal government can be sued for breach of contract only to the extent that it consents to such litigation. The Tucker Act consents to such suits. ${ }^{25}$ Given that limitation, government contract obligations cannot serve as support for the broad principle that Congress has the authority to entrench laws. Conceivably, any future Congress could amend the Tucker Act to say that a particular contract or class of contracts is not enforceable.

Third, even where courts have found that a legislature is bound by the contractual promises of a former legislature, the remedy is simply damages, not enforcement of a legislative scheme that the future body does not favor. The Tucker Act traditionally authorized only cases that sought

22. For a fuller discussion of the utility and constitutionality of the filibuster, see Catherine Fisk \& Erwin Chemerinsky, The Filibuster, 49 STAN. L. Rev. 181 (1997).

23. The Supreme Court's interpretation of the Contracts Clause has limited its importance as a constraint on government actions. In Home Building \& Loan Association v. Blaisdell, 290 U.S. 398 (1934), the Court upheld a state law imposing a moratorium on foreclosure of farm mortgages and accorded the government the authority to abrogate contracts to serve important purposes. Since the nineteenth century, only twice has the Supreme Court invalidated state laws impairing the obligations of contracts. In Allied Structural Steel Co. v. Spannaus, 438 U.S. 234 (1978), the Court declared unconstitutional a state law that required employers leaving a state to set aside money for employees' pensions. In United States Trust Co. v. New Jersey, 431 U.S. 1 (1977), the Court held that state and local governments are limited in their ability to abrogate their own contracts.

24. United States Trust Co., 431 U.S. at 25-26 (ruling that a state government's interference with its own contracts warrants heightcned scrutiny).

25. 28 U.S.C. $\$ 1491$ (a) (1996) (placing jurisdiction over contract claims in the U.S. Court of Federal Claims) 
money damages. ${ }^{26}$ In the Supreme Court's much-discussed Winstar decision, its latest foray into this particular legal thicket, the divergent opinions of the justices were together on that simple point. All agreed that Congress was free to change the accounting rules for thrift institutions, even where it abrogated an agency's earlier commitment to the banks. But under certain circumstances the government might have to compensate the plaintiffs for their resulting losses. ${ }^{27}$

Finally, the Supreme Court has made it clear that government contracts cannot limit the ability of future legislatures to pass general legislation. Rather, they can only limit a legislature's attempts to pass specific bills aimed at the obligation in question. In Stone v. Mississippi, the Court expressly addressed this issue and held that Article I, Section 10, of the Constitution did not limit the ability of legislatures to adopt laws that they believed to be reasonable exercises of the police power ${ }^{28}$ The Court declared, " $[\mathrm{N}] \mathrm{o}$ legislature can curtail the power of its successors to make such laws as they may deem proper in matters of police." 29

Having addressed these preliminary points, we now turn to the constitutional and practical reasons why we believe that one legislature has no power to bind a future one.

II

Is ENTRENCHMENT OF ORDINARY LegisLation CONSISTENT With THE Specific Provisions of the Constitution?

The Supreme Court has long held that legislative entrenchment is unconstitutional. In Ohio Life Insurance \& Trust Co. v. Debolt, the Court held that a legislature could not limit the ability of its successors to impose taxes. ${ }^{30}$ Chief Justice Taney, writing for the Court, stated:

The powers of sovereignty confided to the legislative body of a State are undoubtedly a trust committed to them, to be executed to the best of their judgment for the public good; and no one Legislature can, by its own act, disarm their successors of any of the powers or rights of sovereignty confided by the people to the legislative body .... ${ }^{31}$

26. See United States v. John C. Grimberg Co., 702 F.2d 1362, 1363 (Fed. Cir. 1983). The Federal Courts Improvement Act of 1982 expanded the availability of injunctive relief, but only in cases seeking money damages. The law now provides: "To afford complete relief on any contract claim brought before the contract is awarded, the [Claims Court] shall have exclusive jurisdiction to grant declaratory judgments and such equitable and extraordinary relief as it deems proper, including but not limited to injunctive relief." 28 U.S.C. $\$ 1491(a)(2)$. The class of cases in which equitable relief may be awarded is very limited, however.

27. United States v. Winstar, 518 U.S. 839 (1996).

28. 101 U.S. 814,818 (I879).

29. Id. (quotation omitted).

30. 57 U.S. ( 16 How.) 416, 431 (1853).

31. Id. 
Likewise, in Newton $v$. Commissioners, the Supreme Court held that the Ohio legislature could move its state capitol, despite a prohibition of such an action enacted thirty years earlier. ${ }^{32}$ Declaring that the legislature does not have the power to bind future legislators, the Court explained:

Every succeeding Legislature possesses the same jurisdiction and power ... as its predecessors. The latter must have the same power of repeal and modification which the former had of enactment, neither more nor less. All occupy, in this respect, a footing of perfect equality. This must necessarily be so in the nature of things. It is vital to the public welfare that each one should be able at all times to do whatever the varying circumstances and present exigencies touching the subject involved may require. A different result would be fraught with evil. ${ }^{33}$

The Court applies this principle with equal force to the U.S. Congress. In Reichelderfer v. Quinn, the Court stated flatly that one Congress cannot impose its will on its successors. ${ }^{34}$

Professors Posner and Vermeule would change this rule. They acknowledge that courts and constitutional law experts have uniformly condemned the idea of entrenchment, but urge us to take another look at the constitutional arguments. Interestingly, they do not argue that one can find explicit authority in the Constitution for the power of one Congress to bind another. Instead, they focus on the arguments made by opponents of entrenchment and contend that these arguments are insufficient to sustain a prohibition of entrenchment. Such an approach, however, does not adequately establish the constitutional basis for allowing one Congress to limit the ability of its successors to enact law. Rather, it operates as if there were a constitutional presumption in favor of entrenchment, a presumption that must be overcome by specific evidence in the constitutional text. We argue, on the other hand, that a presumption against entrenchment would make more sense. In any case, examination of the constitutional arguments advanced by Posner and Vermeule reveals why the Supreme Court has consistently condemned legislative entrenchments. In the following sections we examine each of their principal arguments and conclude that there is ample support in the Constitution for the prohibition of entrenchment.

\section{A. The "Vesting Clause" of Article I, Section 1}

Professors Posner and Vermeule begin their constitutional analysis by considering whether the "Vesting Clause" of Article I by itself prohibits legislative entrenchment. The "Vesting Clause" states that "[a]ll legislative

32. 100 U.S. $548,563(1879)$.

33. Id. at 559; see also Stone v. Mississippi, 101 U.S. 814, 818 (1880).

34. 287 U.S. 315,318 (1898) (stating that "the will of a particular Congress ... does not impose itself upon those to follow in succeeding years"). 
powers herein granted shall be vested in a Congress of the United States." ${ }^{35}$ They argue that nothing within this straightforward grant of legislative power to Congress creates any limit on Congress's ability to entrench statutes. $^{36}$

The problem with this argument is that it is too narrow; it focuses only on one clause in Article I rather than on the Article as a whole. The "Vesting Clause," which grants legislative power to Congress, should not be examined in isolation but together with the clauses that define how that power may be exercised.

Article I, Section 7, defines the exclusive manner in which Congress may exercise its legislative powers. ${ }^{37}$ It provides that Congress may act only through passage by both houses of Congress and either signature by the President or override of a presidential veto. Legislative entrenchment would prevent a Congress from enacting laws through this procedure. In essence, a statute that requires supermajority approval for legislative change alters the constitutionally mandated procedure for enacting laws. Indeed, a statute that prohibits its own repeal destroys the legislative power as to that subject matter entirely. It should be obvious that Congress, by statute, cannot alter the constitutional procedures for enacting laws. Yet this is exactly what entrenchment does.

Professors Posner and Vermeule attempt to bolster their argument about the Vesting Clause by pointing to sunset clauses in numerous existing laws. They argue,

[R]ooting the rule against entrenchment in the equal authority of successive legislatures is hard to square with Congress's undisputed authority to enact laws containing sunset clausesclauses that cause a statute to lapse by operation of law, after a defined period. Sunset clauses are the mirror image of entrenching clauses and might also be said to control the authority of later legislatures .... ${ }^{38}$

To the contrary, sunset clauses are not at all analogous to entrenching provisions. A sunset clause in no way ties the hands of successor legislators. The new Congress is completely free to reenact the lapsed provisions in their entirety or with modifications. A sunset clause is the enacting legislature's choice to limit the scope of its action temporally, not to restrict the power of any future legislature to act as it sees fit. Indeed, sunset clauses are the antithesis of entrenching legislation. A sunset clause frees future legislatures from being constrained even by the existence of a

35. U.S. ConsT. art. I, § I.

36. Posner \& Vermeule, supra note 3, at 1674-76.

37. Immigration and Naturalization Serv. v. Chadha, 462 U.S. 919, 951 (1983) (declaring unconstitutional the legislative veto and explaining that the only permissible method for legislative action is through the procedure provided in Article 1, Section 7).

38. Posner \& Vermeule, supra notc 3, at I676. 
law. ${ }^{39}$ The new legislature in essence gets to decide de novo how to proceed. That is exactly the opposite of entrenchment, which restricts the ability of a future legislature to decide at all.

The general structural provisions delineating the legislative power in Article I, therefore, provide strong support for the notion that one legislature may not bind another. Ultimately, what is most disturbing about the argument advanced by Posner and Vermeule is that it has no stopping point. Believing in the wisdom of its choices, anxious to secure its hardfought legislative wins, distrusting what future majorities might want, a legislature might choose to entrench every law. Professors McGinnis and Rappaport describe what the political landscape would look like under such a regime:

In so far as one legislature could bind a subsequent one by its enactments, it could in the same degree reduce the legislative power of its successors, and the process might be repeated until, one by one, the subjects of legislation would be excluded altogether from their control, and the constitutional provision, that legislative power shall be vested in two houses, would be to a greater or less degree rendered ineffectual. ${ }^{40}$

Nor do Professors Posner and Vermeule provide a limit in the form that entrenchment might take. They envision a legislature protecting a law by requiring a supermajority, such as a two-thirds vote, for revision or repeal. Under their argument, a three-fourths or a seven-eighths or a $99 \%$ vote would also be permissible. ${ }^{41}$ Indeed, a complete preclusion of revision or repeal would be allowed. They articulate no constraints on entrenchment. Their approach leaves little left of the democratic principle of majority rule.

\section{B. The Article V Amendment Power}

Professors Posner and Vermeule next explore the relevance of the Article $\mathrm{V}$ amendment process. They note that the Constitution contains several kinds of entrenchment. It entrenches all of its provisions by virtue of the difficulty of altering them through the cumbersome amendment process detailed in Article $V$ (requiring, in the case of congressionally proposed amendments, supermajorities in both the Congress and the state legislatures). Indeed, Article $\mathrm{V}$ makes one provision, the provision governing

39. It is quite true that a sunset provision makes life harder for legislators who continue to support the legislation because they have to recreate their legislative majority and overcome practical obstacles to legislative action all over again when sunset looms. As we argue in Part V, however, these practical difficulties are not the same as binding entrenchment and to conflate the two types of obstacles robs entrenchment of all its meaning.

40. John O. McGinnis \& Michael B. Rappaport, The Constitutionality of Legislative Supermajority Requirements: A Defense, 105 YALE L.J. 483, 506-07 (1995).

41. Posner \& Vermeule, supra note 3, at $1668,1672,1691$. 
representation in the Senate, virtually unamendable. ${ }^{42}$ Professors Posner and Vermeule recognize that the entrenchment of these provisions does not settle the quite different issue of whether it is permissible for the legislature to make ordinary laws difficult to change. They write, "Article V, then, simply does not speak to the disagreement between the anti-entrenchment and the pro-entrenchment positions." ${ }^{, 43}$

Despite this concession, however, they argue that the entrenchment of constitutional amendments in Article $\mathrm{V}$ gives rise to an inference that entrenchment by ordinary legislation should also be permissible. According to Posner and Vermeule,

The real relevance of Article $\mathrm{V}$ is that it supplies an analogy in support of the pro-entrenchment argument. Article $V$ famously entrenched a handful of constitutional provisions against subsequent amendment. ... If constitutional framers may entrench constitutional provisions against later framers, why may not legislatures entrench statutory provisions against later legislatures? $?^{44}$

They answer that there is no reason. They write that "the permissibility of statutory entrenchment should follow a fortiori from the permissibility of constitutional entrenchment. After all, entrenched legislation, unlike an entrenched constitutional amendment, can at least be overturned by a constitutional amendment in the ordinary course. $\$ 45$

This argument, however, ignores the profound differences between a constitution and a statute. The key distinction between the two lies in the difficulty of altering a constitution. Indeed, the entire purpose of a constitution is to shield some matters from the ordinary political processes. ${ }^{46}$ Whether the U.S. Constitution, a state constitution, or a city charter, the distinctive feature of a constitutive document is that it is more difficult to change than a statute or an ordinance. Article V, of course, is the provision in the U.S. Constitution that defines the amendment process and makes constitutional revisions so difficult. That constitutional procedure, however, provides no basis for concluding that the entrenchment of statutes is permissible. Professors Posner and Vermeule do not just blur the distinction between constitutions and statutes; they obliterate it.

Put another way, a constitution is meant to place some matters outside of the normal legislative power and, for that matter, beyond the powers of

42. Article V provides that "no state, without its consent, can be deprived of its equal suffrage in the Senate." U.S. ConsT. art. V.

43. Posner \& Vermeule, supra note 3, at 1681 .

44. Id.

45. Id. at 1682.

46. See Erwin Chemerinsky, Interpreting the Constitution 27-36 (1987); Jon Elster, Ulysses and the Sirens: Studies in Rationality and IrRationality 36 (1984); Jed Rubenfeld, Freedom and Time: A Theory of Constitutional Self-Government 163-95 (2001). 
all of the branches of government. But a legislature has no power to accomplish that same result by tying the hands of future sessions of the legislature without going through the amendment process. To concede such power through the device of entrenchment would amount to an end-run around the Framers' carefully considered amendment provisions. ${ }^{47}$ Professors Posner and Vermeule commit a basic logical fallacy; they assume that because entrenchment is sometimes acceptable, it is always constitutionally permissible. To the contrary, the use of entrenchment in a constitution provides no support for entrenchment via statutes. In fact, it proves a basis for opposing the practice. It is for exactly this reason that the Supreme Court in the famous Carolene Products footnote said that there must be "more exacting judicial scrutiny" when legislation "restricts those political processes which can ordinarily be expected to bring about repeal of undesirable legislation. ${ }^{\circ 48}$

In drawing their analogy, Professors Posner and Vermeule also ignore the significance of the difference in origin between the U.S. Constitution and ordinary statutes. Early state constitutions had mostly emanated from their own legislatures, and the Framers consciously sought to provide the federal Constitution with greater democratic legitimacy. Moreover, the Framers were well-aware that the Articles of Confederation had not been submitted directly to the people, and that this may have contributed to their political weakness. ${ }^{49}$ Thus, they concluded that the new Constitution had to be submitted to and approved by separate conventions in each state. This is not a minor or incidental distinction. In McCulloch $v$. Maryland, it was at the very core of Chief Justice John Marshall's holding. There he declared:

The government proceeds directly from the people.... The assent of the states, in their sovereign capacity, is implied, in calling a convention, and thus submitting that instrument to the people. But the people were at perfect liberty to accept or reject it; and their act was final. It required not affirmance, and could not be negatived, by the state governments. ${ }^{50}$

47. Professors McGinnis and Rappaport reinforce this point by observing that the formidable amendment requirements in the Constitution would be meaningless if the same result could be reached in many cases by the simple device of passing nonrepealable legislation on the subject, and that it is thercfore illogical to suppose that the Framers believed in the principle of entrenchment for ordinary bills. McGinnis \& Rappaport, supra note 7, at 395, 408-11.

48. United States v. Carolene Prods. Co., 304 U.S. 144, 152 n.4 (1938).

49. See Gordon S. Wood, The Creation of the American Republic, 1776-1787 275 (1969) (describing Thomas Jefferson's view that the difference betwecn ordinary legislation and the Constitution is that the latter sets forth fundamental principles and the "natural rights of mankind" while the former may not).

50. 17 U.S. (4 Wheat.) 315, 403-04 (1819). 
The Supreme Court then concluded that, as a result of this process, "[t]he government of the Union ... is, emphatically and truly, a government of the people." 51

Legislative authority, by contrast, stems from the Constitution. That crucial difference in the source of legitimacy was familiar to the Framers and strongly influenced their decision to submit the proposed Constitution to separate state ratifying conventions, not to state legislatures. ${ }^{52}$ It follows that Congress can act only if it has authority stemming from the text of the Constitution. Professors Posner and Vermeule ignore this basic difference between the Constitution and statutes. It should be clear that Congress only has authority to entrench statutes if it is provided for in the Constitution. At best, Posner and Vermeule argue that the Constitution does not explicitly prohibit entrenchment, but that does not provide the constitutional authority necessary for congressional action.

In fact, there is another way in which the Article $\mathrm{V}$ amendment process provides a strong basis for the claim that entrenchment is unconstitutional. By entrenching legislation, one Congress is diminishing the power of future sessions of Congress; some of the legislative authority vested in Congress by the Constitution will thus no longer be present by virtue of the entrenchment provision. This again alters the framework of government set forth in the Constitution, though not through the amendment process as prescribed by Article V. ${ }^{53}$ Rejecting this practice, the Supreme Court stated, " $[\mathrm{N}] \mathrm{o}$ one legislature can, by its own act, disarm their successors of any of the powers or rights of sovereignty confided by the people to the legislative body...."54 If the Constitution is to remain higher law, this principle must continue to be respected.

51. Id. at 404 .

52. Madison, Hamilton, and other leaders of the day often spoke of the differences in legitimacy between constitutions and legislativc cnactments, and distinguished between the basic law of the Constitution and the law as enacted by the Congress. Hamilton, for example, in Federalist No. 22, argued that the Articles of Confederation suffered from a lack of legitimacy because of their adoption proccss, which did not directly stem from the people. The FedERALIST No. 22 (Alexander Hamilton). By contrast, the new Constitution would derive directly from "We the People." Alexander HAMILTON: WRITINGS 251 (Lib. of Am. ed. 2001). The powerful idea that constitutions are different from acts of the legislature and emanate directly from the sovereign power of the people is traced in Wood, supra note 49.

53. See Brett W. King, Deconstructing Gordon and Contingent Legislative Authority: The Constitutionality of Supermajority Rules, 6 U. CHI. L. SCH. RoundTABle 133, 188 (1999). King argues:

[T] he legislative powers granted to the Congress by the Constitution therefore cannot be modified, diminished or enhanced by mere acts of Congress, but only through constitutional change. To be a Constitutional legislature implicitly means Congress must have all of the authority granted to it by its higher charter, and so any attempt to "tie the hands" of a legislative body are inconsistent with its constitutional status and therefore impermissible.

54. Ohio Life Ins. \& Trust Co. v. Debolt, 57 U.S. 416, 431 (1853). 


\section{The Argument from Electoral Cycles}

Professors Posner and Vermeule also briefly respond to the claim that the Constitution's specification of electoral cycles prevents entrenchment. The late Professor Eule argued that entrenchment is inconsistent with the provisions of the Constitution that specify the terms of office and manner for electing members of Congress. ${ }^{55}$ Posner and Vermeule disagree and say that " $t]$ hese Clauses simply establish the electoral cycle; for example, they would prevent a Congress from extending the terms of members."

What Professors Posner and Vermeule ignore is that entrenchment does indeed allow members of Congress to effectively extend their terms in office beyond those prescribed in the Constitution. Imagine that Congress passes a statute saying that no law enacted in that session of Congress can be changed by the next session of Congress except by a unanimous vote of both houses. Nothing in Posner and Vermeule's argument would prevent this type of entrenchment. Indeed, imagine an even more extreme form of entrenchment: In November 2004, the Democrats win back control of both the House and the Senate. In December, before the change-over occurs, the Republicans enact a law providing that no existing law can be repealed or modified by the next session of Congress except by unanimous vote. This maneuver would be constitutional under Posner and Vermeule's analysis. They offer no basis for finding any entrenchment unconstitutional. Yet the effect of such a law is, as Professor Eule argued, to undermine the electoral cycles mandated by the Constitution; the people's newly elected representatives would possess no legislative power.

\section{The Rulemaking Clause of Article I}

We must turn to another section of Article I, however, for the strongest textual evidence that specific provisions of our Constitution prohibit the entrenchment of ordinary legislation. In our view, the Rulcs of Proceedings Clause in Article I, Section V, which we shall call the Rulemaking Clause, provides the best constitutional basis for arguing that legislative entrenchment is not permitted by our Constitution. ${ }^{57}$ Since the scope and importance of that provision are not commonly appreciated, it deserves extended attention. Professors Posner and Vermeule briefly discuss the Rulemaking Clause, but do not analyze its implications. ${ }^{58}$ They confine themselves to pointing out, correctly in our view, that the phrase "each House" refers not to each succeeding legislative body in temporal terms, but merely to the

55. Eule, supra note 1, at 405.

56. Posner \& Vermeule, supra note 3 , at 1683.

57. The full text of the Rulemaking Clause reads as follows: "Each House may determinc the Rules of its Proceedings, punish its members for disorderly Behaviour, and, with the Concurrence of two thirds, expel a Member." U.S. Const. art. 1, § 5, cl. 2.

58. Posncr \& Vcrmeule, supra note 3 , at 1683. 
two houses of Congress. ${ }^{59}$ What they fail to appreciate is that original intent, the long-standing practices of all three branches of government, and federal court decisions have all applied the Rulemaking Clause more widely than one might expect from reading the text. Far from being the internal housekeeping provision that its bare words might suggest, the Rulemaking Clause has emerged since the beginning of our national government as a powerful constitutional principle that effectively walls off the entire process of enacting legislation from outside scrutiny or control. Like several other brief clauses or phrases in the written Constitution, it has taken on a significance and power not easily apprehended from the words alone. $^{60}$

One of us has recently written an extensive account of the origins and meaning of the Rulemaking Clause, and we need not repeat all of that analysis here. ${ }^{61}$ The idea that every legislative body must have the plenary power to control its own enactment process (and, more obviously, its internal staff, property, etc.) has deep roots in British and American law. Indeed, something akin to the Rulemaking Clause was present in early state constitutions in America. The Framers inserted the Rulemaking Clause in the Constitution without any explicit discussion. ${ }^{62}$ Two important points emerge from our analysis of the Clause in relation to entrenchment. First, its scope is broad enough to prohibit the entrenchment of ordinary legislation; and second, its application by the federal courts renders nonjusticiable any effort to enforce entrenchment provisions against a subsequent legislature bent on repeal or amendment.

The first significant decision interpreting the Rulemaking Clause came in 1892, when the Supreme Court adopted the enrolled bill rule, insulating legislative enactments from challenges based on faulty enactment procedures. ${ }^{63}$ In United States v. Ballin, decided the same day, the Court

59. Id.

60. As one of us has argued elsewhere, the bicameralism and presentment principles that have in recent years become a powerful tool in Supreme Court jurisprudence are good examples of this phenomenon. While the Court has emphasized the importance of the "finely wrought and exhaustively considered" enactment process in such cases as Immigration and Naturalization Service v. Chadha, 462 U.S. 919 (1983), and Bowsher v. Synar, 478 U.S. 714 (1985), and has insisted that it bc followed scrupulously, examination of Article 1, Section 7, shows that bicameralism and presentment do not appear in the form of general provisions governing the workings of Congress. Rather, they are written as a preliminary clause in the description of the presidential veto mechanism, one of the most hotly debated and carefully considered provisions of the Constitution. See John C. Roberts, Are Congressional Committees Constitutional?: Radical Textualism, Separation of Powers, and the Enactment Process, 52 CASE W. Res. L. Rev. 489, 522-24 (2001).

61. See generally Roberts, supra note 60.

62. Id. at $528-29$.

63. Field v. Clark, 143 U.S. 649 (1892). The enrolled bill rule can be viewed as an analytical corollary to the Rulemaking Clause. It has the very powerful effect of shielding even the most obvious errors and procedural abuses from judicial scrutiny (so long as a bill is properly attested to by the appropriate officer of each house of the legislative body), and thus transcends the merely procedural. Justice Scalia, often no fan of Congress's way of doing business, is a strong supportcr of the enrolled 
made its most comprehensive statement about the scope of the Rulemaking Clause, in upholding an unusual interpretation of the constitutional quorum requirement. ${ }^{64}$ The justices described the Rulemaking Clause in sweeping language, making it clear that only where internal legislative rules impinge on fundamental personal liberties, or where they conflict with other specific rules in the Constitution, would a federal court have the power to consider the validity of congressional rules and procedures on the merits:

[W]ithin these limitations all matters of method are open to the determination of the house, and it is no impeachment of the rule to say that some other way would be better, more accurate, or even more just. It is no objection to the validity of a rule that a different one has been prescribed and in force for a length of time. The power to make rules is not one which once exercised is exhausted. It is a continuous power, always subject to be exercised by the house, and within the limitations suggested, absolute and beyond the challenge of any other body or tribunal. ${ }^{65}$

Subsequent federal court cases, most of them from the circuit courts, have elaborated upon this broad interpretation of the Rulemaking Clause. Either by explicitly stating that the Rulemaking Clause bars the inquiry, or by using familiar justiciability rules, courts have avoided interference with the enactment process in Congress.$^{66}$ No court has ever ruled on the validity of a House or Senate rule or practice involving the enactment process leading up to the presentment of a bill for action by the President. The only cases in which courts have passed on the interpretation or validity of congressional rules have involved the rights of witnesses from whom compelled testimony was sought by a congressional committee. ${ }^{67}$

A review of case law shows the wide scope of congressional practices approved by courts under the Rulemaking Clause. They involve not merely procedural rules of various types, which seem clearly encompassed by the Clause, but also matters of some substance and importance that seem to

bill rule. In United States $v$. Munoz-Flores, 495 U.S. 385 (1990), a case involving whether a revenue bill properly originated in the House, Justiee Scalia wrote:

We should no more gainsay Congress' official assertion of the origin of a bill than we would gainsay its official assertion that the bill was passed by the requisite quorum.... Mutual regard between the coordinate branches, and the interest of ccrtainty, both demand that official representations regarding such matters of internal process be accepted at face value.

Id. at 410-11 (Scalia, J., concurring).

64. 144 U.S. 1 (1892).

65. Id. at 5. While Justice Brewer in Ballin also mentions a third limitation, that there should be a "rcasonable relation" between a rule and its object, this dictum is inconsistent with the holding and reasoning of the opinion and has never been applied in a subsequent Supreme Court case. Justice Brewer wrote, "With the courts the question is only one of power." Id. He continued, "The constitution empowers each house to determine its rules of proceedings." $I d$.

66. For a full analysis of the case law, see Roberts, supra notc 60, at 530-41.

67. United States v. Reinecke, 524 F.2d 435 (D.C. Cir. 1975); Yellin v. United States, 374 U.S. 109 (1963); Christoffel v. United States, 338 U.S. 84 (1949). 
involve a stretching of the constitutional structure. In Ballin, the Supreme Court permitted Congress to define "quorum" as it appears in the Constitution with great flexibility ${ }^{68}$ Courts have allowed Congress to dilute the voting power of the minority party by manipulating the membership percentages on committees. ${ }^{69}$ Congress has been allowed to "present" passed bills to the President for approval or veto through its committees or agents while in recess. ${ }^{70}$ The Senate has been allowed to "try" an impeachment case using a special committee, leaving only the debate and formal vote for the full body..$^{71}$ In one of the most discussed cases in recent years, the federal courts refused to decide a challenge to the House's new rule requiring a three-fifths vote in order to change tax rates. ${ }^{72}$ Perhaps most amazing of all, the courts refused to intervene when the House allowed nonmembers to vote in its committees, even on final reporting of a bill, and in the Committee of the Whole House, arguably a considerable expansion of the legislative body explicitly set out in Article $\mathrm{I}^{73}$

The preceding discussion might lead one to believe that federal courts often have an opportunity to pass on the validity or interpretation of congressional rules. In fact, litigants never ehallenge most rules. Standing and justiciability problems prevent recourse to the courts in this arena. ${ }^{74}$ Moreover, the mass of existing rules, practices, and traditions of the House and Senate show how far Congress can go in crafting its own enactment processes, even where these processes seem to conflict with general

68. We frequently overlook the great importance of a definition of "quorum" that allows business to be transacted with only a few members present, unless someone objects to the absence of a constitutional majority of members required "to do business." U.S. ConsT. art. l, §5, para. l. We realize today that no large legislative body could operate without a "presumptive quorum" practice, but in fact the Framers actually discussed this question and many were strongly opposed to a loose quorum requirement that would allow a small "junto" of members (in George Mason's phrase) to control business. II ReCords of the Federal Convention of 1787 (Max Farrand ed., rev. ed. 1966) 252. As Oliver Ellsworth put it: "lt would be a pleasing ground of confidence to the people that no law or burden could be imposed on them by a few men." $1 d$. at 253 . They viewed the requirement that a majority of members be present to conduct business as an important safeguard, but the Court in Ballin allowed this specific requirement to be overridden by the Rulemaking Clausc and common sense.

69. Vander Jagt v. O'Neill, 699 F.2d 1166 (D.C. Cir. 1983).

70. See United States v. Kapsalis, 214 F.2d 677 (7th Cir. 1954) (approving presentment of a bill to the President by a congressional committee after the Congress had adjourned sine die); Mester Mfg. Co. v. Immigration and Naturalization Serv., 879 F.2d 561, 571 (9th Cir. 1989) (stating that "[iln the absence of express constitutional direction, we defer to the reasonable procedures Congress has ordaincd for its internal business... The Constitution also requires extreme deference to accompany any judicial inquiry into the internal governance of Congress.").

71. Nixon v. United States, 506 U.S. 224, 226 (1993). Though this case technically involved a separate provision of the Constitution, giving the Senate the "sole power" to try impeachments, the approach and reasoning are the same as in cases involving the Rulemaking Clause.

72. Skaggs v. Carle, 110 F.3d 831 (D.C. Cir. 1997). As we observe elsewhere in this Essay, the court explicitly noted in its opinion that this was not a case of successful entrenchment, since the House could, and did, waive the rule by a majority vote. $l d$. at 835 .

73. Michel v. Anderson, 14 F.3d 623 (D.C. Cir. 1994). The practice involved participation by the delegates from the District of Columbia, Puerto Rico, the Virgin Islands, and American Samoa.

74. See Roberts, supra note 60 , at 535-37. 
constitutional principles or democratic ideals. ${ }^{75}$ The Constitution leaves to the House and the Senate the power to determine the contours of the term "passed" in Article $\mathrm{I}^{76}$ Both houses have committee systems that wield enormous power over the course of enactment. The House has its Rules Committee, which can strangle or mangle legislation desired by the majority. The Senate has its tradition of unlimited debate and its unusual cloture rule. ${ }^{77}$ Both houses have numerous procedural rules and practices which can thwart legislative action in a given situation. ${ }^{78}$ Pushing the authority of the Rulemaking Clause the farthest, both houses have voting rules and practices that allow a very small number of members to be present in order to enact legislation in the absence of objection, despite the quorum requirement of the Constitution. Indeed, one of us has argued that legislation may pass without any actual "event" of passage occurring on the floor at all, so long as the resulting bill is correctly engrossed by the proper official of the body. ${ }^{79}$

The Rulemaking Clause of the Constitution, then, stands for a very important and expansive principle: that the House and the Senate alone and together control every aspect of the enactment process. The following example illustrates the relevance of this point to the issue at hand. Suppose that Congress One passes a regular bill. Included in this bill is a provision that either prevents its repeal or prevents its repeal without use of some particular procedural rule like a supermajority. Some years later, however, Congress Two concludes that the Act (which was signed into law by the President) no longer serves the public interest and seeks to repeal it. Professors Posner and Vermeule argue that the previously enacted rule against repeal (or procedural limitation on consideration of the repeal bill) is valid and should be enforced. Yet it is easy to sce how doing so would

75. Of course, as we discuss elsewhere, the American Constitution is not a purely democratic document, but a specialized instrument designed to meet the needs of our particular system. Indeed, in numerous ways the constitutional structure thwarts the will of transient majorities, preserves the power of the smaller states, and makes the passage of any legislation difficult. The Framers felt that these obstacles would preserve individual freedom, protect federalism, and ensure that laws would not be precipitously enacted. Despite all the structure and procedure, however, Congress can act with lightning speed when a clear majority demands action. See infra Part V.

76. Again, for a fuller discussion, see Roberts, supra note 60.

77. See generally Fisk \& Chemerinsky, supra note 22; see also TIEFER, supra note 20, at 691766.

78. Examples include repeated quorum calls or dilatory motions to adjourn.

79. See Roberts, supra note 60, at 525-26. Occasionally, important bills are passed by this unanimous consent procedure, though it was designed to move along unimportant legislation. Of course all legislation is legally and constitutionally equivalent. An excellent recent example is the Contract With America Advancement Act of 1996, which contained, among other things, provisions for congressional disapproval of agcncy rules. The entire legislative package was passed in the Senate by unanimous conscnt under a previous agreement, and there is no actual moment of passage recorded in the Congressional Record. See 104 Cong. Rec. S6808 (daily ed. Mar. 29, 1996). 
violate the Rulemaking Clause ${ }^{80}$ Under this scenario, Congress Two would not have the full freedom to control its own enactment process under Article I, Section 5. But where does this authority to modify or take away the enactment discretion of Congress Two come from? The Rulemaking Clause cannot be repealed through ordinary legislation. Surely, as the Supreme Court has held, Congress One cannot overturn a constitutional provision guaranteeing that each Congress over time will exercise equal plenary authority over its enactment process. ${ }^{81}$ Yet that is precisely what Professors Posner and Vermeule propose.

This argument seems most powerful in the case of procedural entrenchment. For the Rulemaking Clause to have meaning, it must at least vest control over such key procedural elements of the enactment process in each House at any point in time. Similarly, we would argue that the broad interpretations given to the Rulemaking Clause in our history and tradition, and the decisions of the federal courts discussed above, mean that it would also apply to substantive entrenchment. What greater restriction on the enactment process can be imagined than a rule stating that a particular amendment or repeal could not be voted on by the House and Senate? What greater breach in the constitutional wall separating ordinary legislative power from outside control (again, excepting those rare instances in which individual rights vis-à-vis Congress are involved) could there be than a prohibition on legislating in specific circumstances? Moreover, it would seem analytically absurd to interpret the Rulemaking Clause as prohibiting one Congress from imposing special burdens on future repeal of legislation but at the same time allowing that Congress to prohibit repeal altogether.

Professors Posner and Vermeule do not discuss these arguments, except to suggest that each succeeding Congress is still formally equal under the Rulemaking Clause, in that it too may bind its successors by entrenching legislation. ${ }^{82}$ This response simply does not stand up to scrutiny. While each succeeding Congress may be equal in a forward-looking sense, Congress Two, in our example, is certainly not equal to Congress One. Unlike Congress One, Congress Two may not enact the full range of legislation it otherwise would have the authority to enact under Article I. Indeed, one area of substantive policy making (or perhaps many areas, if the

80. Actually, it is inconceivable that a federal court would interfere with a decision by Congress Two to ignore the entrenchment provision and repeal the statute. Congress has consistently taken the position that its rules can always be waived or repealed, even when they have been put into statutory form, as many were in the post-war congressional reorganization acts. Courts have agreed, as Posner and Vermeule concede. See Metzenbaum v. FERC, 675 F.2d 1282 (D.C. Cir. 1982). The cloturc rule in the Senate raises special problems. See supra notes 18-22 and accompanying text.

81. See Ballin v. United States, 144 U.S. 1, 5 (1892) ("The power to make rules is not one which once exercised is exhausted. It is a continuous power, always subject to bc exercised by the house ....").

82. Posncr \& Vermeule, supra note 3, at 1676. 
principle is established) will have been declared off limits by Congress One, making it impossible for a majority of Congress Two to repeal or amend the relevant statute.

Perhaps Professors Posner and Vermeule would contend that the Rulemaking Clause confers upon Congress One the power to enact a rule forbidding Congress Two from acting in a certain way. Yet such an interpretation would vest in the earlier Congress the power to modify or repeal a constitutional provision by ordinary legislation. Allowing Congress One to adopt, say, a particular committee structure for itself and to impose that structure on future Congresses as well would clearly violate any plausible interpretation of the Rulemaking Clause. That clause guarantees that both Congress One and Congress Two will have the full authority to structure their proceedings as they see fit. The Rulemaking Clause simply cannot be interpreted to include the authority to repeal itself.

\section{E. Summary}

In the final analysis, there are several specific constitutional provisions upon which to base the argument that one Congress may not bind its successors by entrenching legislation. We have seen that some support can be gained from the Vesting Clause and the more general provisions of Article I; from the electoral cycles; and, by negative implication, from the amending provisions of Article V. Perhaps the strongest support for the anti-entrenchment position, however, comes from the Rulemaking Clause, to which Professors Posner and Vermeule give scant attention. That argument, as we have discussed above, does not depend on a strained or creative interpretation of general constitutional provisions, but rather has been solidly endorsed by the Supreme Court. We conclude that the Court has been justified in doing so.

\section{III}

Is ENTRENCHMENT OF ORdinaRy LEgISLATION CONSISTENT With THE Underlying Principles of OUR Representative Democracy?

As we have noted, Professors Posner and Vermeule attempt to show that entrenchment is constitutional by responding to arguments that others have made asserting that entrenchment by Congress violates the Constitution. This approach offers no basis for assessing the constitutionality of entrenchment generally, including entrenchment by state legislatures or local governments. In fact, focusing on why such entrenchment is objectionable for any legislative body helps to further illuminate why Congress, too, may not obstruct its future sessions. In this section, we hope to show that, apart from the textual arguments discussed above, there are strong arguments to be made that entrenchment by any legislative body is 
unconstitutional. This involves identifying and examining some key principles that underlie our representative form of government at all levels.

\section{A. The Principle of Democratic Accountability}

The first idea we examine is the principle of democratic accountability. Few would dispute that democratic accountability is a bedrock American constitutional value. Among other things, accountability allows voters to deny reelection to incumbent officeholders and to elect new representatives who will change the law, if voters are displeased with the status quo. The principle is embodied in various seetions of the Constitution, including provisions that limit the terms of officeholders and specify their method of selection, ${ }^{83}$ an assurance that every state will be guaranteed a Republican form of government, ${ }^{84}$ and provisions that extend the right to vote to an ever-expanding electorate. ${ }^{85}$ Indeed, one scholar has correctly remarked that democratic self-governance is a "fundamental, albeit implicit, postulate of the Constitution." 86

Entrenchment weakens and in some cases eliminates the possibility of accountability. Through entrenchment, the voters are denied the ability to effect change by electing new officials. As Professor Eule explains:

Just as members of Congress lack power to extend their terms beyond those set by the Constitution, they may not undermine the spirit of that document by immutably extending their influence beyond those terms. Each election furnishes the electorate with an opportunity to provide new direction for its representatives. This process would be reduced to an exercise in futility were the newly elected representatives bound by the policy choice of a prior generation of voters. ${ }^{87}$

Professors Posner and Vermeule do not deny that democratic accountability is a basic constitutional principle. Nor do they deny that entrenchment undermines accountability. Instead, they question whether "simple

83. See U.S. ConST. art. 1, $\S 2, \mathrm{cl} .1$ (terms of House members), cl. 3 (method of selecting House members), cl. 4 (method of filling House vacancies); $\$ 3$, cl. 1 (terms of senators), cl. 2 (staggered Senate terms); $\$ 4$ (state role in House and Senate elections); art. II, $\$$ I, cl. I (term of President), cls. 24 (operation of Electoral College); amend. XII (Electoral College procedure); amend. XVII (direct election of senators); amend. XXII (limiting President to two terms).

84. U.S. CONST. art. IV, $\$ 4$.

85. U.S. CoNst. amend. XV (ensuring the right to vote regardless of race, color, or previous condition of servitude), amend. XIX (ensuring right to vote regardless of sex), amend. XXIV (setting the voting age at 18). See New York v. United States, 505 U.S. 144 (I992) (declaring unconstitutional a federal law which forced states to clean up their nuclear wastes on the grounds that commandeering the states undermines democratic accountability and violates the Tenth Amendment); see also Printz v. United Statcs, 52I U.S. 898 (1997) (declaring unconstitutional a federal law that required state and local law enforcement personnel to do background checks before issuing permits for firearms).

86. D. Bruce La Pierre, Political Accountability in the National Political Proccss-The Alternative to Judicial Review of Federalism Issues, 80 Nw. U. L. Rev. 577, 642 (1986).

87. Eule, supra note 1, at 404-05. 
majoritarianism" is possible at all. ${ }^{88}$ Relying upon public choice theory, they claim that it is impossible to say that any law reflects a majority's preference ${ }^{89}$ Moreover, they posit that "[i]f there are political or logistical costs to repealing legislation-and there surely are-then an earlier Congress 'binds' a later Congress by enacting legislation that cannot be costlessly repealed or changed." 90

As we make clear below, we do not argue that all aspects of our constitutional system reflect an underlying principle of simple majoritarianism. We focus solely on the requirement of majority rule in enacting ordinary legislation. The idea that Congress must make policy through ordinary legislation by simple majority vote is a formal requirement in our system for giving policies legal effect and legitimacy. It does not guarantee actual underlying majority consensus, and indeed no voting requirement can. Like so many other features of the Constitution, it is a working political rule, not a philosophical abstraction. We all understand that the House and Senate Rules, traditions, and culture may in some cases prevent the majority from getting its proposal voted on, and that majorities are made up of people who vote for a variety of conflicting reasons. We even live with the fact that a "majority" vote may only be the vote of a few members present at the time.

Arguments from public choice theory, therefore, seem curiously beside the point. They attempt to show that underlying consensus is often not present even when majorities adopt specific measures, but they do not and cannot affect the constitutionally binding effect of the resulting enactments. Carried to their logical extreme, public choice arguments would make it impossible to have a representative government at all, yet we struggle along assuming that majority votes roughly indicate the will of the legislature and the desires of the people. The requirement of majority rule for ordinary legislation is a key formal and structural principle in our Constitution, despite its real-world flaws. The insights of public choice do not undermine our argument that entrenchment prevents a future majority from expressing its wishes through its elected representatives, however flawed the transmission process might be.

Moreover, supermajority voting requirements of the kind advocated by Professors Posner and Vermeule do not eliminate the problems posed by public choice theory any more than they can bypass the other procedural or practical obstacles to passage of legislation. One could question the underlying validity of a two-thirds vote in a legislative body just as for a majority vote.

88. Posner \& Vermeule, supra note 3, at 1685-86.

89. Id. at 1686 .

90. Id. 
If, as we argue here, the focus instead is on democratic accountability, there is no doubt that entrenchment is inconsistent with a fundamental constitutional precept. This can be illustrated by a simple example. Imagine, again, a state that is strongly in favor of the death penalty. As sometimes happens, though, the legislature is comprised of a bare majority in favor of abolishing the death penalty. With many legislators about to leave office because of term limits, the legislature decides to ban the death penalty knowing that the voters will be angry and will want to elect pro-death penalty replacements. Anticipating this reaction, the legislature includes in the statute entrenchment provisions. Professors Posner and Vermeule cannot deny that accountability is undermined by entrenchment in such circumstances.

Professors Posner and Vermeule counter that all laws "bind" successor legislators in some sense. Yet, as we seek to show, this observation fails to provide a persuasive justification for allowing legislatures to entrench statutes. Indeed, in drawing this analogy, Professors Posner and Vermeule confuse factors that may influence action or inaction with barriers that prevent action altogether. The difference is between a law that can be changed through the usual legislative processes and a law that cannot. Countless factors may influence whether a legislature acts or not, but that does not mean that each of them equally restricts legislative action. As we show at greater length in Part V, entrenchment is different because it places formal, binding obstacles in the path of current majorities seeking to perform their legislative responsibilities.

\section{B. Majoritarianism in Enacting Ordinary Legislation}

Let us return our focus, for a moment, to the federal Constitution and, specifically, to the principle that a simple majority is required to enact legislation. No sophisticated student of the Constitution argues today that the Constitution adheres strictly to the principle of majority rule. The Framers were animated less by a desire for theoretical purity and more by a need to create a working government for a complex society with a particular political history. ${ }^{91}$ The election of senators by state legislators, the composition of the Senate itself, the presidential veto, and other such provisions make it clear that the Framers did not want popular majorities in America to control easily the process of national policymaking. The later-adopted Bill of Rights made it explicit that certain fundamental individual rights were also to be protected against popular majority rule. As a result, it is difficult to generalize about the majestic principle of majority rule. While the Framers

91. See Leonard W. Levy, Introduction to American Constitutional History, 1776-1789, in THE Framing and Ratification of the Constitution 12-18 (Leonard W. Levy \& Dennis J. Mahoney eds., 1987). Levy specifically notes that "[t]he Constitution is basically a political document." $I d$. at 17 ; see also Jack N. Rakove, The Road to Philadelphia, 1781-1787, in id at 100-01. 
had complicated ideas about majority rule in general and included many counterweights to its free exercise, they did belicve in the principle of continuous majority rule when it came to the mechanics of enacting ordinary legislation. ${ }^{92}$

Probably because they did not see the issue as a controversial one, it is difficult to find specific discussion of this issue in the writings of our Framers. We do know that they refused to impose specific limitations upon the power of a majority to enact lcgislation, as they did upon the amcndment process, and for overriding presidential vetoes. Professors Posner and Vermeule, however, rcly upon an obscure quote from Madison's writings acknowledging the existence of some higher type of legislation that is more difficult to amend or repeal. ${ }^{93}$ This appears to be a purely abstract point, since no such class of legislation is mentioned in the Constitution, and since Madison clearly believcd in strict majority rule on the floor of the House and Senate. Indeed, Madison expressed this view in Federalist No. 58 while explaining why the proposed Constitution did not require a supermajority voting requirement for the passage of ordinary legislation. He wrote:

That some advantages might have resulted from such a precaution, cannot be denied. It might have been an additional shield to some particular interests, and another obstacle generally to hasty and partial measures. But these considerations are outweighed by the inconvenience of the oppositc scale. In all cases where justice or the general good might require new laws to be passed, or active measures to be pursued, the fundamental principles of free government would be reversed. It would be no longer the majority that would rule; the power would be transferred to the minority. ${ }^{94}$

\section{The Framers' Experiences With Legislative Bodies}

Another way to understand the views of the Framers on the question of whether one legislature may bind another is to examine their own life

92. Professors McGinnis and Rappaport usc somewhat different approaches to the problem of discerning the Framers' views. However, they also come to the conclusion that the Framers did not endorse the idea of entrenchment of ordinary legislation. McGinnis \& Rappaport, supra note 7, at 39293.

93. Posner \& Vermeule, supra note 3, at 1677. Examination of the comment in question shows that it was a reply to one of Jefferson's speculations about government and part of a highly abstract exchange. James MADISON, Writings 474 (Lib. Of America ed., 1999). Madison nowhere in the letter suggested that he believed entrenchment was an appropriate part of our political system, much less part of the Constitution. Nor is there anything in Madison's other writings suggesting that he bclieved that cntrenchment of lcgislation was a good idea. Jeffcrson, though, argucd that all acts of onc political generation should lapse at the end of that generation, which he thought would occur every nincteen years. A stronger anti-entrenchment position can hardly be imagined. "The Earth Belongs to the Living," Letter from Thomas Jefferson to James Madison (Sept. 6, 1789), in THOMAS JEFFERSON: WRITINGS 959 (Lib. of Am. ed., 1984).

94. The Federalist No. 58 (James Madison). 
experiences - experiences that, we argue, hclped shape their ideas about how the new Congress would operate. As we have noted, those gathered in Philadelphia were practical men, political leaders from their respective states seeking to creatc a working government for an emerging nation. They did not embrace a pure version of separation of powers, a pure democracy, or a pure federal structure. Rathcr, they created a unique political amalgam. ${ }^{95}$ They recognized that a stronger national government was needed, but they also feared excessive central power. They wanted a strong legislative branch, but also recognized the potential for majority abuse of power. They were convinced of the need for an elected chief executive with substantial authority, even though they blamed the English kings for overriding their rights and wanted no American monarch. The Framers balanced the interests of small and large states, of north and south, of federalists and those concerned with state sovereignty, and they accomplished that feat with a complicated system of checks and balances that defies easy summary.

Above all, however, the Framers were experienced politicians, and they recognized at every turn in their deliberations that the Constitution would have to be submitted to the people for their approval. While we tend to forget it today, ratification was not a foregone conclusion in 1787. The national debate over the Convention's handiwork was lengthy and intense, and the Framers may well have prevailed only because they supported adding a Bill of Rights as soon as the new government was formed..$^{96}$ In fact, the vote in several state conventions was very close. ${ }^{97}$

Given this background, the notion that a legislative body could pass legislation that could not be repealed by a subsequent legislature would

95. Robert Dahl makes this point in his recent essay about the undemocratic features of the Constitution. See Robert A. Dahl, How Democratic is the American Constitution? 38 (2002). See also William B. Gwyn, The Indeterminacy of the Separation of Powers in the Age of the Framers, 30 WM. \& MARY L. Rev. 263, 263 (1989) ("Both the framers and the men participating in the first administration under the new Constitution (often, of course, the same persons) were concerned more with improving the efficiency and eapacities of the national government than with creating a system of government based on the abstract maxims of political philosophers."); Michael J. Malbin, Congress During the Convention and Ratification, in THE FRAMING and Ratification of THE CONSTITUTION, supra note 9I, at 185 ("Anyone who reads the convention debates looking for theoretical completeness is bound to be disappointed. The Constitution may rest on important theoretical assumptions, but the document itself is a practical one ....").

96. See Robert A. Rutland, Framing and Ratifying the First Ten Amendments, in THE FRAMING AND RATIFICATION OF THE Constitution, supra note 91, at 306 ("The major roadblock to ratification was the lack of a bill of rights, and not until its supporters conceded that they would offer amendments in the First Congress was a fair trial for the Constitution assured.").

97. Rhode 1sland boycotted the Convention, and initially rejected the proposed Constitution in a popular referendum. It eventually ratified the Constitution through a convention in 1790 by a vote of thirty-four to thirty-two. The vote was close in Massachusetts, Virginia, New York, and New Hampshire. In only three states was the vote unanimous. See Robert A. Rutland, Ratification of the Constitution, in I Encrclopedia of the American Constitution 18-19, 21 (Leonard W. Levy \& Kenneth L. Karst eds., 2d ed. 1986). 
certainly have struck the Framers as outrageous. The power to pass "permanent" legislation which binds future groups of elected representatives gives enormous power to the earlier legislature and with it the potential for enormous mischief. ${ }^{98}$ Madison and the other principal Framers were acutely aware of the dangers posed by an unchecked legislature, even while acknowledging that the legislative body in any democratic government must of necessity be the most powerful of the three branches. Indeed, their views about the practical problems of the proposed national legislature were influenced by the nation's recent experiences with state legislatures after independence and with the Articles of Confederation. These experiences led them to conclude, as we shall see, that each majority in time should have full power to enact ordinary legislation. It is to a description and analysis of these experiences that we now turn.

\section{State Legislatures}

Many of those who gathered in the summer of I787 to draft a new Constitution had been members of the various state legislatures. ${ }^{99}$ The widespread belief was that those legislative bodies had behaved irresponsibly in many cases, and that the states in general had adopted too few checks on the power of legislatures. ${ }^{100}$ Some of the specific limitations on the new federal legislature, such as the prohibition on state impairment of the obligation of contracts and the supremacy of federal over state law, reflected this concern. Even in his loftiest musings on the superiority of republican government, Madison understood that majorities, especially because of the influence of factions and special interests, could pass unwise legislation and expand the limits of their proper policy-making spheres. ${ }^{101}$ The Philadelphia debates and the subsequent debates in the states during

98. For a full analysis of the practical reasons for our opposition to the entrenchment principle, see infra Part V.

99. Alphabetical sketches in the Concise Dictionary of American Biography (1964) reveal that at least eighteen of the fifty-five men who attended at least a portion of the Convention's sessions had served in state legislatures. There were probably more. The eighteen include Madison, Gerry, Luther Martin, Paterson, Robert Morris, Mason, Wythe, C.C. Pinckney, and Rutledge.

100. See WooD, supra note 49, at 403-09. Wood argues that many Americans had lost faith in legislatures as a result of the abuses of the 1780s, writing, "In the 1780's the Americans' inveterate suspicion and jealousy of political power, once concentrated almost exclusively on the Crown and its agents, was transferred to the various state legislatures." Id at 409. See also Forrest McDonald, Novus Ordo Seclorum: The Intellectual Origins of the Constitution 143-83 (1985).

101. Madison's most famous statement of the dangers of unchecked majorities is in The Federalist No. 10. During a speech in the Convention over the question of whether the federal executive should be elected, he made this comment (according to his notes): "Experience had proven a tendency in our government to throw all power into the Legislative vortex. The Executives of the States are in general little more than Cyphers; the legislatures omnipotent. If no effectual check be devised for restraining the instability and encroachments of the latter, a revolution of some kind or other would be inevitable." 11 Records of the Federal Convention, supra note 68, at 35. 
the ratification process made this theme clear. ${ }^{102}$ Because of their experiences, the Framers were anxious both to include in the new Constitution a list of enumerated powers for Congress and to create a strong counterweight in the form of an executive veto. ${ }^{103}$ In this way, the new legislature, while powerful enough to create a truly national government, would also be saved from the worst majority excesses that had occurred in the states.

Madison's orchestration of the constitutional ratification process in the states starkly illustrates his lingering distrust of legislative power. $\mathrm{He}$ and his colleagues sought to distinguish constitution-making from ordinary legislation by submitting the Constitution to separate constitutional conventions in each state, with members selected solely for that purpose. ${ }^{104}$ It was this process that the Framers believed would enshrine the democratic legitimacy of the Constitution.

\section{The Articles of Confederation}

The Framers' attitude toward legislative power was also influenced by their experiences with the Articles of Confederation. Too often, we forget that the Philadelphia Convention itself was the product of a political movement to amend the Articles of Confederation, a movement sparked by the nation's most sophisticated political leaders. Indeed, more than half of the fifty-five men who attended some part of the Philadelphia Convention, including almost all of the Convention's leaders, had been members of the Continental Congress either before or after the Articles of Confederation

102. Writing to Jefferson about the desirability of a Bill of Rights as an aid to ratification of the Constitution in the states, Madison made it clear that he considered the specific checks and balances of the new Constitution much more important than a written Bill of Rights in restraining the excesses of popular legislatures. He wrote, "Repeated violations of these parchment barriers have been comnitted by overbearing majorities in every State." Letter from James Madison to Thomas Jefferson (Oct. 17, 1788), in MADISON, supra note 93, at 420.

103. Randolph's original resolutions at the Convention actually proposed an even stronger check on legislative power: a Council of Revision consisting of representatives from both the executive and judicial branches. 1 Records of the Federal Convention, supra note 68, at 20, 96-105. Some delegates favored an absolute executive veto. $11 \mathrm{id}$. at 200.

104. Madison noted at the Convention that the state legislatures had an inevitable conflict of interest in being asked to approve a strong federal constitution. At any rate, in order to give maximum credibility and strength to the new central government, he argued that the Constitution "should be ratified in the most unexceptionable form, and by the supreme authority of the people themselves." Id. at 123 . He returned to this theme in The Federalist No. 40. For a general discussion of the decision to bypass the state legislatures and require ratification by only nine states through popular conventions (despite the requirement of Articlc VIII of the Articles of Confederation that amendments must be agreed to by all states), see Catherine Drinker Bowen, Miracle at Philadelphia 228-33 (1966); Jack N. Rakove, Original Meanings: Politics and ldeas in the Making of the Constitution 94-130 (1996). The indefatigablc William Crosskey assembled numerous statements made by advocates of the Constitutional Convention supporting the idea that the new Constitution should properly be ratified by special state conventions and not by the existing state legislatures. WILLIAM W. Crosskey \& William Jeffrey, Jr., ill Politics and the Constitution in the History of the United States 370-73 (U. of Chi. Press 1980). 
were adopted. ${ }^{105}$ By the time they convened in Philadelphia, these men had concluded that the Articles of Confederation were incapable of meeting the needs of the newly independent nation. ${ }^{106}$ Rather than merely modifying the document, however, Madison and others convinced the Convention to propose a wholly new governmental structure, a step that in retrospect looks breathtaking in its audacity. ${ }^{107}$

The Framers' bill of particulars against the Articles was long. The document created only a loose confederation of independent states, and gave too few powers to the central government. ${ }^{108}$ Because the Articles provided for no central executive authority, they prevented the government from enforcing the few important national laws that were passed. The ultimate product, according to the Framers, was a government that failed to function in the best interests of the American public. ${ }^{109}$

It is important to note, however, that the defects of the Articles of Confederation were not just in their substantive limitations, such as the lack of direct taxing power. The Framers also had ample reason to complain about the day-to-day operation of the Congress under the Articles. Several of the procedural rules governing the functioning of the Continental Congress contributed to their frustration: ${ }^{110}$ The most glaring defect was the requirement that ordinary types of legislation be enacted only with the approval of a supermajority. Article IX, paragraph 6, stated that for a specified list of substantive actions (covering, in fact, most of the

105. Perusing the entries in the Concise Dictionary of American BIOGRaPhy, supra note 99, we count twenty-nine such men, including Madison, Wilson, Gerry, Sherman, Hamilton, Franklin, both Morrises, Dickinson, Randolph and Charles Pinckney.

106. In preparing for the Convention, Madison wrote an important paper in 1787 entitled "Viees of the Political System of the United States," which he drew upon during the debates and later in his contributions to The Federalist. MADISON, supra note 93, at 69. Gordon Wood, in his influential study of the period, concludes that by the mid-1780s, the Congress under the Articles had "virtually ceased trying to govern." WooD, supra note 49, at 359 . During the debates in Philadelphia, there were many references to the weakness of the existing governmental system. Edmund Randolph rcferred to the "imbecility of the existing confederacy." I RECORDS OF THE FEDERAL Convention, supra note 68, at 255. James Wilson noted that he had been a member of Congress under the Articles for six years and could attest to its inefficiency and powerlessness. $I d$. at 343 . Madison stated that the country groaned under the "weakness and inefficiency" of the Articles. Id. at 467.

107. Bruce Ackerman, among others, emphasizes the revolutionary nature of this step. See BRUCE A. Ackerman, We The People: Foundations 167-68 (1991).

108. The most comprehensive history of the period is Merrill Jensen, The New Nation: A History of the United States During the Confederation, 1781-1789 (1950). Jensen acknowledges the Articles' defects, but also argues that they formed an indispensable transition between the separate colonies and the eventual national union created by the Constitution. In a sense, the Congress was also an executive body under the Articles. The Congress carried out laws first through its committees, and later created the beginnings of permanent executive departments. $I d$. at 50 , 55.

109. Id.

110. See Jack N. Rakove, The Beginnings of National Politics: An Interpretive History of The Continentral Congress 355 (1979). Rakove points out that the Continental Congress before the Articles had also been extraordinarily inefficient. $I d$. at 201. 
important subjects of legislation), the votes of nine of the thirteen states were needed. That requirement often prevented the Continental Congress from effectively exercising the legislative power to tax, provide for a national defense, and sponsor internal improvements.

Making matters worse, the supermajority required for approval was nine of the thirteen states, not just two-thirds of the members of Congress. Indeed, even for unimportant legislative measures not falling under the nine-state rule, seven states' votes were required for passage, not a majority of those present. Because members of Congress were frequently absent and there was constant turnover of membership, Congress often could not conduct any business at all. ${ }^{111}$ If only seven states' delegations were in attendance, all would have to agree for any action to be taken. Important legislation, of course, could not be passed even by all seven.

Finally, the Articles also required that all voting be by states, ${ }^{112}$ which reflected their origin as a loose compact among sovereign states, driven by necessity rather than the product of careful deliberation. State delegations could have from two to seven members. ${ }^{113}$ A majority of a state's delegation had to vote for a matter in order to be counted. The absence or illness of some of the delegation meant that the state might not have a vote at all. The same would be true if both members of a two-member delegation were present, but the members disagreed on the question at hand. Finally, if one member of a two-member delegation was absent from Congress, which was not an unusual occurrence back then, the state could not even be counted for quorum purposes. ${ }^{114}$

With this immediate experience in mind, it is not surprising that the Framers wanted the new Congress to be a more effective decision-making body than the old one. They wanted a Congress that would not be constrained, except in a few particular cases, by the kind of supermajority requirements that had rendered the Continental Congress ineffective. Instead, they wanted the new Congress to be able to adopt policies by majority

111. Madison's letters are full of references to this problem. "Congress have continued so thin as to be incompetent to the dispatch of the more important business before them." Letter from James Madison to Thomas Jefferson (Mar. 19, 1789), in MADIsoN, supra note 93, at 65. "Congress continue to be thin and of course do little business of importance." Letter from James Madison to George Washington (Mar. 16, 1787), in MADISON, supra note 93, at 83. Six months before the new Congress was to be formed, he reported that the old Congress had not seen nine states in attendance "for some time," and not even the minimum of seven for unimportant business in the last week. Letter from James Madison to Thomas Jefferson (Oct. 17, 1788), in MADISON, supra note 93, at 418. He continued, "It is pretty certain that there will not again be a quorum of either number within the present year; and by no means certain that there will be one at all under the old Confederation." Id.

112. ARTICLES OF CONFEDERATION art. 5, para. 4-5 (U.S. 1781).

113. Id. art. 5, para 2.

114. On these procedural problems, see generally RAKOVE, supra note 110 , at 355 
consensus. ${ }^{115}$ Throughout the Convention debates, the delegates were determined to avoid the procedural defects of the Articles and consciously adopted a simpler procedural model. ${ }^{116}$ Some of these same discredited rules, such as voting by States, were proposed for the new Congress. All were rejected, however, in favor of more conventional quorum and voting requirements. ${ }^{117}$ While they limited the substantive powcrs of Congress in Article I, the delegates included almost no procedural requirements that interfered with a majority's ability to pass bills in the House and Senate.

Given these goals, the Framers surely would have found it laughable for one to argue that their new Congress could adopt legislation that permanently bound future majorities. More particularly, the idea that one Congress might have the power to impose upon a future legislature the dreaded supermajority requirements that had paralyzed government under the Articles was the very vice they sought to eradicate when they drafted the Constitution. ${ }^{118}$

\section{Summary}

Close examination of the practical political goals of the Philadelphia Convention and of the Framers' experiences with contemporary legislative bodies, as well as their own writings, demonstrates that it is highly unlikely

115. Madison concluded: "Experience shows that the confederation is radically defective, and we must in a new national government, guard against those defects." I RECORDS OF THE FedERAL CONVENTION, supra note 68 , at 497.

116. For example, Alexander Hamilton commented:

To give a minority a negative upon the majority (which is always the case where more than a majority is requisite to a decision) is in its tendency to subject the sensc of the greater number of that of the lesser number. Congress from the non-attendance of a few states have been frequently in the situation of a Polish Diet, where a single vote has been sufficient to put a stop to all their movements. A sixtieth part of the Union, which is about the proportion of Delaware and Rhode Island, has several times been ablc to oppose an intire [sic] bar to its operations.

1 Bernard Bailyn, cd., Debates on the Constitution 511 (Library of Am. ed., 1993). "The organization of Congress, is itself utterly improper for the exercise of these powers which are necessary to be deposited in the Union." Id. at 515.

117. A proposal to vote by states in the new Senate provoked especially spiritcd opposition from thosc with cxperience with the Articles of Confederation. Madison recited the example where one member of a two-member delegation held up approval of a measure favored by six states for threc days, until he was finally given some other legislative favor for his vote. 1 RECORDS OF THE FEDERAL CONVENTION of 1787 , supra note 68 , at 554 . James Wilson asserted that equal state votes would make it too hard to legislate and would merely continue the most important procedural flaw of the Articles: "The greatest fault of the existing Confederacy is its inactivity." $11 \mathrm{id}$. at 10 . William Pierce argued that the "equality of votes under the Confederation" was the source of its greatest problems. $1 \mathrm{id}$. at 467. As in ncarly all modern legislative bodies, the Constitution requires a majority of those present for rccorded votes only, and it specifies supermajorities in a few special situations. Voting in the House and Senate is by individual member. As we discuss elsewhcre, the quorum requirement has from the beginning becn interpreted loosely, so that measurcs may be passed by voice vote with less than a majority present, so long as no member questions the absence of a quorum. See supra p. 1792-93.

118. Hamilton substantiates this point in The Federalist, Number 22, wherc he makes an eloquent case for the requirement of majority rulc for ordinary legislation. 
that the delegates would have viewed either substantive or procedural entrenchment as legitimate. Their suspicion of unchecked legislative power and their recent experiences with runaway state legislatures would have led them to reject substantive entrenchment. Their experience with supermajority rule under the Articles of Confederation would have led them to reject procedural entrenchment.

Indeed, that the Framers and the members of state ratifying conventions accepted both procedural and substantive entrenchment mechanisms within the provisions of the Constitution itself merely serves to underscore the differences they saw in the sources of legitimacy for constitutions and ordinary legislation. The Framers believed that the Constitution was fundamental law springing directly from the people, while ordinary legislation was adopted by a majority of their representatives in a carefully balanced and checked governmental system. The course of ratification through state constitutional conventions selected directly by the people of each state rather than from their elected legislatures completes the point. It is hard to understand how Professors Posner and Vermeule could conclude that entrenchment of ordinary legislation would have been acceptable to the founding generation.

IV

Is Entrenchment of Ordinary Legislation Wise as a Matter of National Policy?

As we have noted, the overall thrust of Professors Posner and Vermeule's arguments is that entrenchment of ordinary legislation ought not to be dismissed out of hand as both judges and commentators have generally done. To this end, they devote a section of their essay to some reasons why serious policy makers might actually want to employ the device in order to bind future legislatures. We believe that these reasons prove inadequate upon closer examination. This is particularly true because Posner and Vermeule invariably discuss the advantages of procedural entrenchment (usually a supermajority voting requirement) ${ }^{119}$ and ignore the case for substantive entrenchment. This is hardly surprising, since articulating the desirability of permanent, nonrepealable laws is a daunting challenge indeed. In what follows we discuss both types, but emphasize the dire consequences of enacting laws that cannot be repealed.

\section{A. The Purported Benefits of Legislative Entrenchment}

What then, according to Professors Posner and Vermeule, are the supposed advantages of allowing a legislature to entrench laws? Posner and Vermeule first argue that entrenchment allows the government to make

119. Posner \& Vermeule, supra note 3, at 1670-73. 
credible future commitments, both to those outside and those inside the government. ${ }^{120}$ As to outside actors, they use the example of creditors who might impose a lower interest rate if they can be certain that the debt will not be repudiated. ${ }^{121}$ As to intragovernmental measures, they cite the base closing process as an example where binding entrenchment might improve upon mechanisms that already seek to insulate legislation from future repeal or amendment. ${ }^{122}$

On the general advantages of making permanent government commitments to outsiders, our response is outlined below. We conclude that the advantages come at great risk and must be balanced against the loss of flexibility that entrenchment imposes. We point out that though creditors might be more confident of repayment, the government will be rendered incapable of responding to changed economic conditions that may make repayment bad national economic policy. As to intragovernmental commitments, examples like the base closing process, which utilizes an independent commission to make politically treacherous decisions about closing military facilities, are fundamentally different from entrenchment. Such commitments can be repealed or modified by a majority of Congress at any time. Congress enacts mechanisms like the base closing process, the commission method of determining congressional pay raises, and the complex budget-control machinery of Gramm-Rudman-Hollings in an effort to insulate itself from political pressure and to save itself from its own weakness. Congress, however, may modify or repeal these laws when they produce undesirable results. These examples thus do not provide support for the legitimacy of entrenchment.

Professors Posner and Vermeule also argue that entrenchment would allow members of Congress to "remove contentious issues from the agenda while they focus on other business." ${ }^{23}$ In a related argument, they suggest that entrenchment provides another option for Congress in modulating its policy making between flexibility and stability. ${ }^{124}$ Once again, they seem to be saying that entrenchment is merely an extension of other devices that allow Congress to control its agenda and control the future, and is thus no more objectionable. They offer the example of a hypothetical regime in

120. Id. at 1671 .

121. Id.

122. Id.

123. Posner \& Vermeule, supra note 3, at 1671 . In footnote 18 , the authors note that the idea of a Constitution as higher law has the advantage of taking certain contentious issues off the legislative table. Of course we would agree, but we would contend that constitutions and ordinary legislation are fundamentally different in our system of government. The Framers intended to create a body of basic constitutional law that would be difficult or impossible to change in the future, but accepted almost no restrictions on the enactment of ordinary legislation, which they believed should be under the control of a majority of the House and Senate. See supra pp. 1786-88, 1803-05.

124. Posner \& Vermeule, supra note 3, at 1672-73. 
which all legislation expires after one year, ${ }^{125}$ or the analogous practice of sunsetting legislation after a specified period. ${ }^{126}$ Both kinds of rules, they point out, would give national policy makers greater flexibility in the future than would be the case with ordinary open-ended laws. ${ }^{127}$ If followed for most legislation, however, both would make it impossible for Congress to function. If all legislation had a life of only one year or a specific span of years, every contentious issue would have to be faced anew each year or every few years. The often precarious give-and-take that produced compromises would have to be perpetually reenacted (and probably could not be). For these reasons, most legislation stays on the books until it is repealed.

If Congress can make legislation effective for an indefinite period into the future, in order to put aside controversy and allow other legislative priorities to be addressed, say Posner and Vermeule, what can be so absurd about allowing Congress to entrench its enactments? ${ }^{128}$ We believe that the argument answers itself. Sunset provisions that give legislation a definite life span usually reflect either a slim majority on a controversial measurc, or a solution to a problem that legislators are not sure will work. But a simple majority always has the option when the sunset time approaches (or earlier, for that matter) of reenacting or modifying the law to reflect experience. Entrenchment has an entirely different effect. Because it is binding, substantive entrenchment prevents a future majority from adjusting legislation for experience or from changing its mind about the overall wisdom of the measure. In fact, all of the measures for controlling the temporal effects of legislation in the future are fundamentally different from entrenchment, especially substantive entrenchment, and must have a different and separate justification. ${ }^{29}$

Without a doubt, the idea of enacting permanent legislation or forcing a future Congress to assemble a two-thirds majority to amend or repeal would be attractive to some legislators. Most members, if they considered the question carefully, would oppose the idea of entrenchment in the abstract because they could not be sure who would wield the power. Even so, the temptation to perceive one's own policy judgment as infallible, and to seek effective control over future national policy, is great. Likewise, we would be foolish to deny that entrenchment might not create greater predictability and certainty, both inside and outside Washington; but at what price? The arguments for entrenchment depend heavily on one's point of view. Moreover, whether an entrenched economic or social policy is a

125. Id. at 1703-05.

126. Id. at $1672,1676-77$.

127. Id. at $1672-73,1676-77,1703-05$.

128. Id. at $1672-73,1676-77$.

129. See infra Part V. 
good idea depends on how events develop in the future. What, then, are the practical arguments against entrenchment of ordinary legislation?

\section{B. The Dangers of Entrenchment}

It is no mystery that legislators, judges, and scholars (until Professors Posner and Vermeule) have generally rejected the concept of legislative entrenchment. National policy is made against a backdrop of constant political, economic, and social change, and policies often need to be adjusted in light of changed circumstances. To our minds, the small advantages gained in stability and predictability are far outweighed by the advantages of being able to adapt to unexpected change, to apply wisdom derived from experience, and to correct policy mistakes. In support of our view that legislative entrenchment is dangerous from a policy perspective, we catalog, in this section, a few of the kinds of circumstances, often overlapping and certainly not exhaustive, in which the idea of enacting entrenched legislation would seem foolish and wrongheaded.

\section{Temporary Radical Majorities}

What could provide a better argument against entrenchment, in hindsight, than the Gingrich revolution in the House of Representatives in 1995? A new Republican majority, seething with resentment over the often high-handed leadership of the Democrats in the House over the years, and fueled by ideological fervor, was determined not only to make over the House of Representatives itself but also the nation. Yet after only a few years, most observers agreed that the revolutionaries had overplayed their hand, overestimated their popular support, and been forced to retreat with their leader disgraced. ${ }^{130}$ What if the tool of permanent entrenchment of ordinary legislation had been available to the Republican House majority during the first days of the revolution? ${ }^{131}$ Does anyone doubt that the venerable principle that no legislative body may formally bind its successors allowed a healthy return swing of the political pendulum? No momentary majority with ideas for radical change, whatever its orientation, ought to have the power to enact its policy preferences for all time.

Professors Posner and Vermeule respond to this point by noting that there are many other ways for a transitory majority to do damage, and that

130. See, e.g., Dan Balz, For GOP Fighter, A Confrontation He Didn't Want, WASH. Post, Nov. 7, 1998, at Al; Ceci Connolly, Three Years of Missteps, One Sudden Fall; Path to Gingrich's Ouster Began With Federal Shutdown, Ended in Election Loss, WASH. Post, Nov. 8, 1998, at A1; Alison Mitchcll, The Speaker Steps Down, N.Y. TimEs, Nov. 7, 1998, at Al.

131. The most significant actual effort at entrenchment was the adoption of House Rule 21, clause 5(b), which requires a supermajority to adopt higher income tax rates. The Supreme Court refused to rule on the constitutionality of this mechanism, and the consensus has been that a majority of the House can waive or modify it. See supra note 72 . 
we must have some trust in our normal political processes. ${ }^{132}$ They overlook once again the key element in their own definition of entrenchment: that it is binding on future legislatures. Unwise legislation can be passed under our current system, but a determined majority can and usually will change it in the future. That option is made more difficult or taken away altogether under the eoneept of entrenchment.

\section{Changing National Consensus}

The efforts of the Gingrich Republican House majority may seem like an unrepresentative example, but one can think of many more general instances in which once-popular legislation gives way to a changing national consensus on policy issues. Solutions that seem obviously desirable at the time to members of Congress and the public at large may seem misguided at a later time. For instance, the Reagan tax cuts had wide support in both parties and in the country when they were adopted, but some years later the national consensus was for deficit reduction at all costs. ${ }^{133}$ More recently, with the "War on Terrorism" high on the list of national priorities, deficits have again become tolerable. More speeific examples illustrate the point. The Federal Agriculture Improvement and Reform Act of $1996,{ }^{134}$ a centerpiece of the free market reform agenda championed by the Republicancontrolled House, reversed decades of national policy by eliminating most agricultural subsidies. As commodity prices then fell and criticism from farm states intensified, lawmakers enacted temporary subsidies. ${ }^{135}$ In 2002, only six years later, Congress admitted that its "reform" had resulted in disastrous consequences and completely reversed course. ${ }^{136}$

A particularly instructive example of consensus reversal is the story of the Medicare Catastrophic Coverage Act of 1988 (MCCA). ${ }^{137}$ MCCA was passed after extended consideration both inside and outside Congress, and both parties hailed it as one of the first comprehensive additions to the Medicare program since 1965 . While it provided protection against catastrophic healthcare costs for the elderly, it also required all seniors to pay a small monthly premium and those with the highest incomes to pay an additional tax. The reaction among the elderly and their lobbying groups was instant and intense. The program was in effect for less than a year when Congress repealed the original law with nearly unanimous votes and little

132. Posner \& Vermeule, supra note 3, at I69I-92.

133. See, e.g., The Presidential Tax Cut Moment, N.Y. TIMEs, June 8, 2001, at A24; William Raspberry, True Believer, WASH. Post, Mar. 2, 2001, at A25.

134. Pub. L. No. 104-27, 110 Stat. 888 (1996).

135. See The Farm Aid Fake, WASH. Post, May 30, 2000, at A18.

136. The new law, the Farm Security and Rural Investment Act of 2002, Pub. L. No. 107-71, 116 Stat. 134 (2002), essentially re-establishes the type of farm subsidy entitlements that were phased out in 1996. See Jerry Hagstrom, Final Touches Made to Farm Bill, NAT. J., May 4, 2002.

137. Pub. L. No. 100-360, 102 Stat. 683 (1988). 
serious consideration. ${ }^{138}$ This kind of healthy corrective action when Congress misjudges the political mood of the nation, however, would be impossible if the original statute were entrenched.

What lesson do these examples teach? They demonstrate that, in general, the entrenchment of ordinary legislation would make it difficult (in the case of procedural entrenchment) or impossible (in the case of substantive entrenchment) for a legislature to respond to the inevitable changes in opinion among its members and their constituents regarding the substance of national policy.

\section{Changing Social and Economic Conditions}

Placing the political preferences of the electorate aside, however, we argue that Congress should always be able to revise its policies when social or economic changes expose the inadequacy or even harmful effects of earlier law. To take a recent example, what if Congress, instead of merely pressuring the Finaneial Accounting Standards Board to abandon its proposal to require the expensing of stock options in 1994, had enacted a prohibition against expensing and made the prohibition unrepealable? ${ }^{139}$ Despite the lessons of the corporate scandals of 2001 and 2002, Congress would be unable to correct its view no matter how strong the public and expert consensus might now be. What if the retirement age, nontaxability, and indexed benefit levels of Social Security had been enacted as unrepealable laws during the New Deal? Efforts to adjust to the new realities facing the system would have been not only politically difficult, but literally impossible. What if, as many expect, the heralded welfare reform package supported by both parties in the nineties results, during hard times, in millions of poor mothers and children without any means of support? ${ }^{140} \mathrm{We}$

138. This is also an example of the speed at which Congress can legislate when it feels the heat from a major constituent group. In the House, for example, the Ways and Means Committee had been working on a compromise to retain part of the MCCA, but the House rose up and repealed the entire law without waiting for the committee to report. In the Senate, despite strong support for the original plan, the vote to repeal the MCCA was 99 to 0. See Retreat in Congress: The Catastrophic Care Debate-A Special Report: How the New Medicare Law Fell on Hard Times in a Hurry, N.Y. TIMES, Oct. 9, 1989, at Al. For an in-depth study of the episode, see Richard Himelfarb, CatastrophiC Politics: The Rise and Fall of the Medicare Catastrophic Coverage act of 1988 (1995).

139. The Board recommended that eorporations be required to state the valuc of stock options as an expense in their financial statements in 1994, but opponents in the Senate succeeded in pressuring the Board to shelve its proposal. Led by Senator Lieberman, the Senate passed a resolution disapproving the idea by a vote of 88 to 9 . After the corporate scandals of 2001 and 2002, most observers (though not Scnator Lieberman) advocate expensing stock options to help curb corporate abuses. See Warren Buffett, Editorial, Stock Options and Common Sense, WAsh. Post, Apr. 9, 2002, at A19; Floyd Norris \& Sherri Day, Coke to Report Stock Options as an Expense, N.Y. Times, July 15, 2002, at Al.

140. Little consensus has developed on the overall effect of welfare reform, but many critics worry that its work requirements and firm limits on lifetime bencfits will work enormous hardship on single mothers during reccssionary timcs. See, e.g., Special Supplement: Reforming Welfare Reform, THE American Prospect, Summer 2002. 
would feel fortunate indeed that Congress, in an attempt to "put an end" to the perennial debates and political posturing, had not entrenched the welfare reform legislation as Professors Posner and Vermeule suggest they might. Examples could be multiplied endlessly, all standing for the same incontrovertible truth: legislation that seems wise and just when adopted by one legislature may be rendered obsolete, ineffective, or even harmful by subsequent changes in society and the economy. For these reasons the possibility of repeal or amendment must be preserved at all costs.

\section{Budget Fluctuations}

Though the ebbs and flows of the national budget also reflect changes in national consensus, we feel that they deserve special mention. During times of generous budgets and available tax revenues, federal and state governments may enact expansive social programs and public works projects. The federal government may embark on ambitious military buildups and promise revenue sharing to the states. When budgets are lean, however, these programs must be trimmed or eliminated. What if generous social programs or infrastructure projects are entrenched by the legislature when government coffers are full? Though Professors Posner and Vermeule fail to tell us whether the concept of entrenchment applies to the appropriation of funds, we can see no theoretical difference between appropriations and other legislation. Failure to preserve the legislature's ability to respond flexibly to the ups and downs of the national budget could spell economic disaster for the country and for the states that are also burdened by such expenditures. ${ }^{141}$ Professors Posner and Vermeule do not discuss this potential problem.

\section{Technical Errors}

Professors Posner and Vermeule also ignore the fact that under a regime where entrenchment of ordinary legislation is allowed and encouraged, technical errors in legislative drafting could not be corrected easily. Indeed, while most routine technical errors might be written off as inconsequential, some might not be. Correction by amendment in a statute that is substantively entrenched would be rendered impossible, and the consequences of human error would thus be cast in stone.

141. By the middle of 2002 , the states were facing the worst budget erisis since World War II, with deficits in the billions. While the reasons are, doubtless, eomplex, many observers blame federal programs that mandate state activity without funding it and overly ambitious state programs undertaken in the revenue-rich $1990 \mathrm{~s}$. At least without entrenchment, both the federal and state legislatures have full power to revamp or repeal earlier costly programs. See, e.g., Michelle Ames, State Budget Woes Worse Than Most, Rocky Mountain News, Nov. 27, 2002, at 4A (discussing National Conference of State Legislatures Report, with thirty-one states facing cumulative deficit of $\$ 17.5$ billion); Pam Belluck, Free Spending in Flush Times Coming Back to Haunt States, N.Y. TImes, Mar. 9, 2001, at Al; Joe Leean, Budget Fix: Here are the Hard Choices, Wis. State J., Nov. 20, 2002, at A10. 


\section{Emergency Measures}

Finally, what would happen if legislation enacted during times of national emergency - times where emotions run high and legislators are most likely to bypass the procedural and political obstacles to speedy legislation built into the system - could also be entrenched? Imagine, for instance, if measures inhibiting civil liberties during the World Wars had been written as legislation not subject to repeal. Indeed, imagine how this country would look if the excesses of the Congress during the height of the McCarthy era were also entrenched. The picture is a frightening one.

Let us also use an example that strikes closer to home. Less than a year after the shocking terrorist attacks on the United States in September 2001 , critics were already questioning whether some of the law enforcement and other powers granted to the government in its aftermath were wise as matters of permanent policy. ${ }^{142} \mathrm{Had}$ entrenchment of ordinary legislation been permissible in 2001 , there surely would have been those who would have argued, in the special spirit of that moment, for entrenchment of some of these enactments. Years later, we might well have regretted the decision.

\section{Summary}

The practical case against entrenchment may be summarized as follows: Good government requires that each legislature and each public majority reassess the need for new policies and the costs and benefits of each. No one can foresee the conditions that legislation, however wise or popular when enacted, will face in the future. Every legislative body should be free of binding restrictions on its freedom of action, and that principle is embodied in the settled legal rule that no legislature may bind its successors. We believe that the relatively minor costs of adhering to the rule are outweighed by its vast benefits.

\section{V \\ Are the Real World Obstacles to Ordinary Legislation EQUIVALENT TO ENTRENCHMENT?}

One of the more intriguing arguments that Professors Posner and Vermeule make for acceptance of the entrenchment concept is that it does not differ from other practical, structural, or political obstacles that prevent future legislatures from repealing or modifying earlier enacted statutes. "Entrenchment," the authors assert, "is just a legislative tool, no different

142. See, e.g., Closing the Door to Public Scrutiny, N.Y. Times, June 29, 2002, at A14; Eroding a Privacy Wall, ChI. Trib., Nov. 22, 2002, at 30; A Fight For Freedom, S.F. Chron., Dec. 17, 2002, at A24 (reporting grassroots movement against Patriot Act); Mary Brown Malouf, Utahns on the March, SALT LAKE TRIB., Jan. 19, 2003, at B1 (reporting rally at State Capital against Patriot Act). 
from any other." 143 They claim that such devices serve as means by which a current legislative majority controls the future, and view them as differing only in degree. It is therefore illogical, they contend, to single out entrenchment for being undemocratic. A few excerpts from their analysis help describe their position:

If there are political or logistical costs to repealing legislation-and there surely are-then an earlier Congress "binds" a later Congress by enacting legislation that cannot be costlessly repealed or changed .... ${ }^{144}$

[T] he future is always in the hands of the present, and entrenchment is only one of many devices that the present can use to ruin the future if it so wishes. ${ }^{145}$

The parade of horribles provoked by thinking about entrcnchment statutes is no different from the parade of horribles provoked by thinking about democracy in general. ${ }^{146}$

The problem is that any statute changes the legal status quo and thereby shifts the burden of inertia from the enacting legislature to future legislatures, and might in that sense be said to reduce accountability and to frustrate the future majority's will. ${ }^{147}$

Professors Posner and Vcrmeule end by issuing a challenge to those, like us, who assert that entrenchment richly deserves its current status of total legal and political neglect: "Critics of entrenchment must come to terms with the ability of legislatures to affect the future and explain what makes legislative entrenchment special and worthy of constitutional concern." 148 In this section we answer this challenge by attempting to distinguish all of the ordinary barriers to legislative change from those that entrenchment erects.

Thoughtful students of Congress have long pointed out that the enactment process is consciously designed to make it difficult to pass new laws. ${ }^{149}$ As we note elsewhere, many of the most obvious barriers to quick passage were put in place by the Framers because of their experience with runaway majorities in early state legislatures. ${ }^{150}$ To understand better the

143. Posner \& Vermeule, supra note 3, at 1690.

144. Id. at 1686 .

145. Id. at 1691 .

146. Id. at 1692 .

147. Id. at 1696-97.

148. Id. at 1705 .

149. See Abner J. Mikva \& Eric Lane, Legislative Process 677-85 (2d ed. 2002).

150. See supra pp. 1801-02. The Supreme Court has described the enactment process this way: "The choices we discern as having been made in the Constitutional Convention impose burdens on governmental processes that often seem clumsy, inefficient, even unworkable, but those hard choices were consciously made by men who had lived under a form of government that permitted arbitrary governmental acts to go unchecked ...." Immigration and Naturalization Serv. v. Chadha, 462 U.S. 919,959 (1983). 
full range of these barriers to legislative action, let us posit a situation in which a majority of the current House and Senate come to a clear consensus that some existing piece of legislation is no longer in the public interest and must be repealed or modified. What factors might prevent a majority of the Congress from translating its wishes into law, as might be expected in a truly "democratic" government?

First, Congress is structured so as to inhibit fast legislative action, sometimes preventing it from taking action at all. Some of these structural features are part of the constitutional scheme itself. The existence of two separate houses of Congress, the fact that the Senate tends to represent the interests of states and regions more than the House does, and the existence of a presidential veto which can only be overridden by a supermajority are examples.

Other structural barriers, however, are purely creatures of House and Senate rules. A number of these rules serve as "choke-points"-points at which legislation can be stalled or killed altogether by less than a majority of each House's members. The leadership structures that control Congress's agenda, particularly the often cumbersome committee system to which members must defer in practice, represent one example. Others include the Senate's tradition of unlimited debate (which can prevent a simple majority from prevailing) and the House's Rules Committee (which can effectively keep bills and specific amendments from the floor). Of course each house also has myriad procedural rules that, if deployed aggressively by opponents, can be used to block the majority from winning the day or even having an opportunity to vote on its favored bill.

Political factors can also make it either difficult or impossible for the majority to repeal or modify existing law. It may be too close to an election for the majority to risk undertaking a controversial measure. Key leaders in Congress or in the executive branch may oppose the measure, and others may have to defer to their desires. The President may threaten a veto. Public opinion may be opposed or conflicted, giving the majority pause. Special interest groups with strong influence on members of the majority coalition may also be opposed. Business leaders and members of the executive branch may have come to rely on the statutory provisions in question and will push strongly to maintain the status quo despite logical arguments to the contrary. These, again, are but a few examples.

Finally, even assuming that there is a political consensus and that the structural friction of the enactment process can be overcome, there may be practical or psychological barriers to action. Congress may suffer from ineffective leadership. Members may be, and often are, afflicted by legislative inertia and may not want to revisit past issues, particularly contentious ones. In the modern Congress worthy issues are frequently put aside merely because of the press of legislative business, particularly near the 
beginning of the new fiscal year when appropriations bills must be written and passed. Other legislative items may simply be more important and deserve the time of committees and the floor, despite the merits of the issue in question. Last, and this is often the most important reason, there may be a majority desire for action but disagreement about the specific mechanisms needed to change current law. Competing solutions may kill the effort to repeal or amend, despite the underlying consensus for change. ${ }^{151}$

Are all these factors essentially the same as binding entrenchment of legislation because they limit the ability of future legislative majorities to effect change, as Professors Posner and Vermeule seem to argue? If we find them legally, constitutionally, and politically acceptable, then must we also accept the concept of entrenchment? Three different reasons counsel us to answer no. First, structural, political, or practical barriers to future legislative action do not run afoul of the specific constitutional provision allowing each Congress to control its own enactment process. Entrenchment does. A presidential veto threat, a full legislative agenda, or pressure from powerful special interests may inhibit action, but they do not interfere with Congress's Article I powers. ${ }^{152}$ Second, these barriers do not present the same challenge to the underlying constitutional spirit of representative democracy to the degree that binding entrenchment does. ${ }^{153}$

There is a third, more common-sense answer to Posner and Vermeule's attempt to defend entrenchment by equating it with virtually any other factor that inhibits future legislative action. In our view, lumping together all of these diverse factors-some emanating from the structure of the Constitution, some adopted as congressional rules, some being merely human realities-ultimately proves nothing, because they differ in one crucial respect from Posner and Vermeule's binding legislative entrenchment: they can all be overcome by a determined majority. They may not, in fact, be overcome in all cases where a majority wishes to act, but there is no insurmountable barrier to enactment as in the case of entrenchment. To conceive of all these factors as equally "binding," as Posner and Vermeule would like to do, robs the word of all its meaning. Binding in what sense, we ask? In the sense that it would take hard work, sophisticated knowledge

151. One additional factor should be noted. A few statutes have attained such status over time as to resist change in a very special way. These statutes-the Sherman Antitrust Act, the Administrative Procedure Act, and the Civil Rights Act of 1964, to mention just a few-are unusually hard to amend because the principles embodied in them command strongly coherent majorities over time. They have had a profound impact on the legal system and even majorities are reluctant to tamper. Eskridge and Ferejohn call them "super statutes." See William N. Eskridge, Jr. \& John Ferejohn, Super-Statutes, 50 Duke L.J. 1215 (2001). But of course they can be changed. Professor Popkin traces the idea of statutes with an especially profound influence on the common law to Roscoe Pound. See WILliam D. PoPKIN, Materials on Legislation: Political Language and the Political Process 24-25 (Supp. 2002).

152. See supra pp. 1783-85, 1789-95

153. See supra pp. 1795-99. 
of the legislative process, and political will to overcome them? Surely, when we speak of barriers to change, we mean barriers that are binding in some legal sense: barriers that absolutely prevent the majority from having its way despite overcoming all of the other praetical and political obstacles standing it its way.

Indeed, one can cite many historical examples in which circumstances combine to create unusually fast legislative action. In such cases, the political and practical barriers Professors Posner and Vermeule posit as the equivalent of entrenchment are exposed as nonbinding, their existence being ever-dependant upon the good graces of a majority: When a motivated majority wishes to act, committees can be bypassed, rules can be waived, agendas can be modified, and quick votes can be taken. One of the most dramatic examples involves President Franklin Roosevelt's effort to restore confidence in the banking system after his election in 1932. Roosevelt imposed a bank holiday to prevent a public run on banks, calling Congress into special session five days after his inauguration, on March 9, 1933. A banking bill was passed that same day, and the banks reopened with confidence restored on March 13. ${ }^{154}$ Thus began an unprecedented outpouring of important legislation during the New Deal's "Hundred Days," demonstrating the ability of a majority of Congress to brush aside obstacles that ordinarily slow down important bills. ${ }^{155}$

Another striking example of streamlined lawmaking is the USA Patriot Act, passed with a minimum of legislative consideration after the tragic terrorist attacks of September 11, 2001. ${ }^{156} \mathrm{~A}$ third is President George W. Bush's first tax cut, enacted within only a few weeks after his election in sharp contrast to the usual slow process of developing major tax

154. See generally Arthur M. Schlesinger, JR., The Coming of the New Deal 6-8 (1959). Professor Kennedy describes this remarkable episode more colorfully:

The Bill was read to the House at 1:00 P.M., while some new representatives were still trying to locate their seats. Printed copies were not ready for the members. A rolled-up newspaper symbolically served. After thirty-eight minutes of "debate," the chamber passed the bill, sight unseen, with a unanimous shout. The Senate approved the bill with only seven dissenting votes .... The president signed the legislation into law at 8:36 in the evening.

David M. Kennedy, Freedom From Fear: the american People in Depression and War, 19291945 135-36 (1999).

155. See SCHLESINGER, supra note 154 , at $20-21$, for a list of fifteen important pieces of legislation passed during the "Hundred Days."

156. Pub. L. No. 107-56, 115 Stat. 272 (2001). In early October 2001, both the House and Senate passed bills strengthening certain law enforcement powers in the aftermath of the terrorist attacks. The Administration then put together a eombined bill and pushed it through both houses with great speed. In the House, the bill was first referred to committee, but was immediately brought to a vote by suspension of the rules. The next day the Senate passed the bill without amendment. The New York Times deseribed the process as "the climax of a remarkable 18-hour period in which both the House and the Senate adopted complex, far-reaching antiterrorism legislation with little debate in an atmosphere of edgy alarm...." Robin Toner \& Neil A. Lewis, A Nation Challenged: Congress; House Passes Terrorism Bill Much Like Senate's, But With 5-year Limit, N.Y. Tımes, Oct. 13, 2001, at B6. 
legislation. ${ }^{157}$ Both examples illustrate the power of a highly motivated political majority to act quickly when circumstances are right, despite built-in obstacles in Congress.

Particularly relevant to this discussion are instances in which Congress decides in advance to truncate its consideration of certain legislative business, either because of the importance of the issue or for special political reasons. The most interesting recent example of this phenomenon may be the Congressional Review Act, passed as part of the Contract with America Advancement Act in 1996. ${ }^{158}$ The Congressional Review Act establishes a mechanism for Congress to disapprove agency rules by joint resolution, replacing the older legislative vetoes struck down by the Supreme Court in Chadha. ${ }^{159}$ A key element of the mechanism is a set of rule waivers designed to speed congressional consideration, including an override of the filibuster in the Senate. ${ }^{160}$ Following these expedited procedures, Congress passed a resolution of disapproval for President Clinton's controversial ergonomics rules at the beginning of the new Bush Administration. The Senate debated the resolution for one day, the House for one hour, and the entire process took less than a week. ${ }^{161}$

These examples all show how quickly a majority of Congress can overcome all practical, political, and structural obstacles to action when it truly wishes to legislate. They also show the naivete of Posner and Vermeule's position. What these scholars fail to recognize is that none of those kinds of obstacles to legislation raise any concern for the health of democratic government because such obstacles can be overcome by a motivated majority. They create friction in the legislative process, but they cannot and do not prevent the enactment of necessary laws. Entrenchment is different. Professors Posner and Vermeule have defined it as binding future legislatures, and indeed it does. It prevents the kind of freedom of action by the future legislature that is the essence of representative democracy.

157. Economic Growth and Tax Relief Reconciliation Act of 2001, Pub. L. No. 107-16, 115 Stat. 38 (2001). The legislation spent only one day in the House. The Senate, also for the moment controlled by the GOP, passed a slightly different version after six days of legislative consideration (not all on the floor, of course) and the Conference took only three days. See David E. Rosenbaum, Senate Deflects Numerous Efforts to Alter Tax Bill, N.Y. Times, May 22, 200I, at Al.

158. The Congressional Review Act was section 251 of the Contract With America Advancement Act, Pub. L. No. 104-21, 110 Stat. 847 (1996). It can be found starting at 5 U.S.C. 801.

159. 1mmigration and Naturalization Serv. v. Chadha, 462 U.S. 919 (1983).

160. 5 U.S.C. $\$ 802$ (including special discharge rules, waiver in advance of certain procedural rules, and a limitation of ten hours on Senate debate). The Act speeifically notes that these rule waivers are enacted pursuant to Congress's power under the Constitution's Rulemaking Clause and therefore may be altered by either house at any time. See id. at $\$ 802(\mathrm{~g})$. The special rules are thus not legally binding on Congress.

161. See Steven Greenhouse, House Joins Senate in Repealing Rules on Workplace Injuries, N.Y. Times, Mar. 8, 2001, at A19. 


\section{VI \\ CONCLUSION}

Professors Posner and Vermeule raise an issue of profound importance, and they certainly offer a provocative thesis. They see no constitutional limits on entrenchment and, in fact, they embrace and defend legislative entrenchment as a matter of policy. By contrast, our central goal in this Essay is to defend the well-established principles they attack.

The temptations for entrenchment are enormous. Any legislature would like to make sure that its actions survive long into the future. Any legislature worries that its hard fought gains will be quickly lost to misguided or differently motivated future sessions. Entrenchment efforts might be motivated by the best intentions, such as the desire to protect reforms of programs like Social Security or tax cuts from change. Professors Posner and Vermeule seek to provide an intellectual and constitutional foundation for such legislative behavior.

Entrenchment, however well-intentioned, violates basic principles of American constitutional law and democracy. Professors Posner and Vermeule's argument warrants close analysis because theirs is the first attempt to challenge the principle against entrenchment that extends back to the roots of Anglo-American law. ${ }^{162}$ On careful examination it is clear that their arguments fail to justify abandoning one of the most basic principles of democratic rule: one session of a legislature cannot tie the hands of another. As we have seen, there are sound arguments that entrenchment of ordinary legislation violates the letter of the Constitution, and that it is unwise as a matter of policy. Most fundamentally, though, Posner and Vermeule do not and cannot deny that entrenchment frustrates democratic accountability by limiting the ability of people through their representatives to change the law. There is no stopping point to the Posner and Vermeule thesis. Any legislature, at any time, could enshrine its actions and prevent its laws from being changed. A legislature could tremendously diminish the power of its successors-and thus of the people-through extensive entrenchments. This simply cannot be right under a Constitution adopted by "we the people" that embodies a commitment to democratic self-government.

162. In one of its most recent discussions of legislative entrenchment, the Supreme Court quoted Blackstone, who clearly articulated "the centuries-old concept that one legislature may not bind the legislative authority of its successors." United States v. Winstar, 518 U.S. 839, 989 (1996) (citing 1 William Blackstone, Commentaries on the Laws of England 90 (1765)). 
